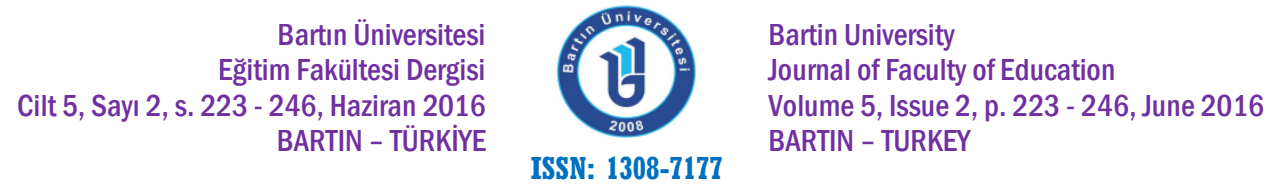

Doi: 10.14686/ buefad.v5i2.5000186142

\title{
Herkes İçin Eğitim 2015 Hedefleri ve Türkiye
}

Şefika Şule ERÇETIN, Prof. Dr., Hacettepe Üniversitesi Eğitim Fakültesi, ssule@hacettepe.edu.tr Ahmet ARIFOĞLU, Eğitim Uzmanı, Milli Eğitim Bakanlığı, axarif@yahoo.com

Öz: Eğitimin ekonomik büyüme ve toplumsal kalkınmaya olan başat etkisi artık bilinmektedir. Bu nedenle eğitim girişimi, 21.yüzyılın bilgi toplumu ve ekonomisinde vazgeçilmez bir politika alanı haline gelmiştir. Bunun için hem ülkeler hem de uluslar üstü çeşitli kuruluşlar sürdürülebilir ekonomik büyüme, insani gelişim ve kalıcı bir barışın sağlanması için eğitim alanında kapsamlı reform hareketleri gerçekleştirmektedirler. Günümüzde en önemli küresel eğitim girişimi, 1990 yılında UNESCO tarafından başlatılan Herkes için Eğitim hareketidir. Çocukların, gençlerin ve yetişkinlerin eğitimden yararlanmasını hedefleyen bu hareketin kapsamı, 2000 yılında gözden geçirilmiş ve 2015 yılına kadar başarılması gereken 6 hedef belirlenmiştir. Bu çalışmanın amacı, Herkes İçin Eğitim hedefleri kapsamında Türkiye'nin 2000-2015 döneminde uygulanan eğitim politikalarını geniş bir perspektiften incelemek ve değerlendirmektir. Nitel araştırma yaklaşımının benimsendiği bu çalışmada, verilerin analizinde doküman incelemesi tekniği kullanılmıştır. Avrupa Birliğine katılım sürecinde olan Türkiye, birçok alanda olduğu gibi eğitim sisteminde de önemli reformlar yapan bir ülkedir. Bu amaca yönelik olarak çalışmada Türkiye'nin bu dönem süresince eğitime yönelik politikaları Herkes İçin Eğitim hareketinin altı hedefine göre değerlendirilmiş ve geleceğe yönelik önerilerde bulunulmuştur.

Anahtar Kelimeler: Herkes için Eğitim, Türkiye, eğitimde kalite, evrensel ilköğretim

\section{Education for All 2015 Goals and Turkey}

Abstract: The dominant effect of education on economic growth and social development is now known. Therefore the education initiative has become an indispensable policy area in the 21st century's knowledge society and economy. For this reason both countries as well as various supranational organizations perform comprehensive reform movements in the field of education to maintaining sustainable economic growth, human development and to ensure a lasting peace. Nowadays, the most important global education initiative, launched by UNESCO in 1990, is the Education for All movement. The scope of this movement which aims children, youngs and adults to benefit from the education was revised in 2000 and the six targets were identified to be achieved by 2015 . The aim of this study is to examine and evaluate Turkey's education policies implemented over the period 2000-2015 from a broad perspective according to Education for All targets. In the study, the qualitative research approach was applied and in the analysis of data, document analysis technique was used. Turkey, in the process of accession to the European Union, makes significant reforms in the education system, as well as in many areas. Towards this objective in this study Turkey's education policy during this period was evaluated according to six targets and some suggestions were made for the future.

Key Words: Education for All, Turkey, education quality, universal primary education 


\section{GíRiş}

Eğitim, bireyin ve toplumun gelişmesini sağladığı, ülkelerin ekonomik ve teknolojik ilerlemesine imkân verdiği için günümüzde vazgeçilmez bir eylem alanı haline gelmiştir. Schultz (1961), gelişmiş ve gelişmekte olan ülkeler arasındaki ekonomik kalkınma düzeyi arasındaki farklılıkların nedenini, ülkelerin sahip olduğu insan sermayesi olduğunu belirtmiştir. Ülkelerin gelişmişlik seviyesinin önemli göstergelerinden birisi olan eğitim; bireyin, toplumun, ülkelerin ve gelecekteki dünyanın şekillenmesinde önemli işlevlere sahiptir. Çünkü eğitim düzeyinin yüksekliği birey için yüksek kazanç ve daha düşük işsizlik oranı; toplum ve ülke açısından ise, vergi gelirlerinde artış, kaliteli sağlık hizmeti, siyasi istikrar anlamına gelmektedir (McMahon, 2006).

Yerel çapta ülkeler, küresel ölçekte ise UNESCO, OECD gibi uluslar üstü aktörler eğitimin belirtilen bu önemli işlevlerinden dolayı eğitim sistemlerinin geliştirilmesine yönelik olarak birçok reform çalışmaları yapmaktadır. Global ölçekte eğitim alanında başlatılan en önemli girişimlerden birisi 'Herkes İ̧̧in Eğitim', diğeri ise 'Bin Yıllık Kalkınma Hedefleri'dir. Özellikle bireylerin eğitime erişiminin arttırılması uzun yıllar boyunca bu iki önemli girişimin temel yaklaşımı olmuştur (Hanushek ve Wossmann, 2007). Küresel düzeydeki bu girişimler ülkeleri de etkilemiş ve bireylere eğitim hizmetinin sağlanması birçok hükümetin ana hedeflerinden birisi olmuştur (UNESCO, 2010). Hangi kapsam ve düzeyde yapılırsa yapılsın tüm bu reform ve girişimlerin temel amacı birey ve toplum için eğitimin niceliksel ve niteliksel açıdan geliştirilmesidir.

2000 yllında Senegal'in Dakar kentinde toplanan Dünya Eğitim Forumunda, 1990 yılında başlatılan Herkes İçin Eğitim (Education for All-EFA) hareketinin genel bir değerlendirmesi yapılmış ve eğitimde istenen düzeye ulaşılamadığı sonucuna varılmıştır (UNESCO, 2015, s.1). Bu forumda belirlenen hedeflere 2015 yılına kadar ulaşmak için gerekli olan hususların ifade edildiği Dakar Eylem Planı kabul edilmiştir. Bu plan kapsamında 6 eğitim hedefi belirlenmiştir. Bu programın temel öncelik alanları; erken çocukluk eğitimi, temel eğitim, genç ve yetişkin beceriler, yetişkin okur-yazarlığı, cinsiyet eşitliği ve eğitimde kalite konularıdır.

Küresel düzeyde bir hareket olan EFA hedeflerinin her bir ülke tarafından başarılması daha iyi bir dünya için gereklidir. Bu hedeflere ulaşılmasında her ülkenin mevcut şartlarından dolayı kendine özgü kolaylık ve zorlukları bulunmaktadır. Türkiye de özellikle 21. Yüzyılın başından itibaren birçok alanda olduğu gibi eğitim sektöründe çok önemli reformlar ve değişiklikler yapan bir ülkedir. EFA döneminde Türkiye'de eğitim sektörü bağlamında yasal düzenlemelerden öğretim programlarına, okullaşma oranlarından eğitim harcamalarına varıncaya kadar birçok niceliksel ve niteliksel değişimler gerçekleştirilmiştir.

Bu çalışmanın amacı, Herkes İçin Eğitim hedefleri kapsamında Türkiye'nin 2000-2015 döneminde yürütülen eğitim politikalarını geniş bir perspektiften incelemek ve değerlendirmektir. Bu nedenle Türkiye'de eğitim alanında yapılan uygulamalar, EFA'nın altı hedefine göre; yasal düzenlemeler, politikalar, eğitim programları, projeler, coğrafi erişim, sayısal gelişmeler ve eğitim harcamaları temaları çerçevesinde analiz edilmiştir.

Dünya genelinde ana eğitim hizmeti sağlayıcısı olan devletlerin eğitimde istenen hedefleri başarması için nitelikli araştırma sonuçlarına dayanan rasyonel, etkili ve eşitlikçi politikalara ihtiyaç vardır (Woessmann, 2003). EFA hedefleri çerçevesinde Türkiye'nin eğitim alanında 15 yıllık döneminin tüm yönleriyle incelenerek değerlendirilmesi 2015 sonrasına yönelik olarak devam eden hedeflere ulaşılmasında uygulanacak olan yeni politikaların belirlenmesi, eski dönemde yapılan yanlış ya da eksik uygulamaların düzeltilmesi ve gelecek hedeflerine ulaşmak için yapılması gereken planların hazırlanmasında kolaylık sağlayacaktır. 


\section{HERKES IÇiN EĞiTiM 2015 HEDEFLERI'NIN GENEL ÇERÇEVESi}

Çocukların, gençlerin ve yetişkinlerin eğitimden yararlanmasını hedefleyen ve küresel bir program olan Herkes İçin Eğitim hareketi UNESCO tarafından 1990 yılında Jomtien, Tayland'da yapılan Dünya Konferansı ile başlatılmıştır. Bu konferansta eğitimin bir insan hakkı olduğunun altı çizilmiş ve tüm insanlık için eğitim hedefleri belirlenmiştir (UNESCO, 2000).

Konferanstan 10 yıl sonra bu süre içinde gerçekleştirilen çalışmaların değerlendirilmesi amacıyla 2000 yılında Dakar, Senegal'de bir Dünya Eğitim Forumu düzenlenmiştir. Bu foruma 164 ülkenin hükümet temsilcileri, bölgesel grupların temsilcileri, uluslararası kuruluşlar, sivil toplum kuruluşları katılmış ve 1990 'I yıllardaki eğitimin ilerlemesi değerlendirilmiştir. Yapılan değerlendirmeler herkes için eğitim hedeflerine dünya ölçeğinde erişilemediğini göstermiş ve Forum tarafından bu hedeflere ulaşılması için yapılması gereken faaliyetleri belirten "Dakar Eylem Çerçevesi" kabul edilmiş̧ir (UNESCO, 2015, s.1).

Dakar Eylem Çerçevesine göre EFA'nın iki ana unsuru bulunmaktadır. Bunlar; 2015 yılına kadar başarılması gereken 6 hedef ile tüm paydaşların katkı sağlayacağı 12 stratejiden oluşmaktadır. Dakar Eylem Çerçevesinde kapsamında yer alan Herkes için Eğitim 2015 hedefleri Tablo 1'de verilmiştir.

Tablo 1

Herkes için Eğitim 2015 Hedefleri

\begin{tabular}{|c|c|c|}
\hline $\begin{array}{l}\text { Hedef } \\
\text { No. }\end{array}$ & Ana Tema & Hedef \\
\hline 1 & $\begin{array}{l}\text { Erken çocukluk } \\
\text { bakımı ve eğitimi }\end{array}$ & $\begin{array}{l}\text { Özellikle en güçsüz ve dezavantajlı çocukları gözeterek, erken } \\
\text { çocukluk bakımı ve eğitiminin iyileştirilmesi ve yaygınlaştırılması }\end{array}$ \\
\hline 2 & $\begin{array}{l}\text { Evrensel ilköğretim / } \\
\text { Temel eğitim }\end{array}$ & $\begin{array}{l}2015 \text { yılına kadar tüm çocukların, özellikle kızların, güç koşullar } \\
\text { altındaki ve etnik azınlıklara mensup çocukların, ücretsiz ve iyi } \\
\text { kalitede bir zorunlu eğitime erişimlerinin ve bu eğitimi } \\
\text { tamamlamalarının sağlanması }\end{array}$ \\
\hline 3 & $\begin{array}{l}\text { Genç ve yetişkin } \\
\text { beceriler }\end{array}$ & $\begin{array}{l}\text { Tüm genç ve yetişkinlerin, uygun öğrenme ve yaşam becerileri } \\
\text { programlarına eşitlik içinde erişimleri sağlanarak, öğrenme } \\
\text { gereksinimlerinin karşılanması }\end{array}$ \\
\hline 4 & $\begin{array}{l}\text { Yetişkin okur- } \\
\text { yazarlığı }\end{array}$ & $\begin{array}{l}2015 \text { yılına kadar, başta kadınlar olmak üzere tüm yetişkinler için } \\
\text { temel / sürekli eğitime eşit erişim olanağı sağlayarak, yetişkin } \\
\text { okuryazarlığı oranını \%50 düzeyinde yükseltmeyi başarma }\end{array}$ \\
\hline 5 & Cinsiyet eşitliği & $\begin{array}{l}2005 \text { yılına kadar ilk ve ortaöğretimde cinsiyet farklılıklarını } \\
\text { ortadan kaldırma ve kızların iyi kalitede bir temel eğitime tam ve } \\
\text { eşit erişimi ve başarıları üzerinde yoğunlaşarak, } 2015 \text { yılına kadar } \\
\text { tüm eğitim kademelerinde cinsiyet eşitliğini sağlama }\end{array}$ \\
\hline 6 & Eğitimde kalite & $\begin{array}{l}\text { Başta okuryazarlık, sayısal beceri ve gerekli yaşam becerileri olmak } \\
\text { üzere, herkes tarafından kabul edilen ve ölçülebilen öğrenme } \\
\text { sonuçlarını başararak, eğitimin kalitesini tüm yönleriyle iyileştirme } \\
\text { ve eğitimde mükemmelliği sağlama }\end{array}$ \\
\hline
\end{tabular}


Tablo incelendiğinde altı EFA amaçlarının bir bireyin hayatı boyunca ihtiyaç duyacağı tüm eğitim kazanımlarını kapsamaktadır. Amaçlarda özellikle eğitimin bir insan hakkı olduğu gerçeğine göre toplumda çeşitli yönlerden dezavantajlı durumda olan bireylere yönelik olarak baskın bir vurgu yapıldığı açıkça görülmektedir. 2000 yılından bugüne Herkes için Eğitim hareketinin altı amacı doğrultusunda katılımcı ülkeler, uluslararası kuruluşlar ve sivil toplum işbirliği içinde çalışmalarını yürütmektedir.

UNESCO Herkes İçin Eğitim 2015 hedeflerine yönelik gelişmeleri ülkeler ve dünya ölçeğinde muhtelif yıllarda yayınladığı raporlar ile izlemektedir. Dakar Eylem Planının yayınlanmasından 2015 yılına kadar toplam 12 adet EFA küresel izleme raporu yayınlanmıştır. Ayrıca Dünya ölçeğinde eğitim gelişmeleri daha net olarak izlemek için Herkes İçin Eğitim Gelişim İndeksi (EDI = The EFA Development Index) geliştirilmiştir. Bu indeks kapsamında bulunan göstergeler aşağıda verilmiştir (UNESCO, 2005, s.136-137):

- Illköğretimde evrenselleşme: Net Okullaşma oranı

- Yetişkin okuryazarlığı: +15 yaş okuryazarlık oranı

- Cinsiyet farklılıkları

- Eğitim kalitesi: Beşinci sınıfa ulaşma oranı

Bir ülkenin eğitim gelişiminin bir ölçüsü olan EDI, EFA amaçlarından dördünü içermektedir. İndeks dört amacı kapsamasına rağmen tüm EFA hedeflerindeki ilerlemeyi yansıtmaktadır. EDI, evrensel ilköğretim, yetişkin okuryazarlığı, cinsiyet eşitliği ve eğitim kalitesi amaçlarını içine almaktadır. EDI, belirtilen bu dört göstergenin aritmetik ortalaması alınarak hesaplanmaktadır. Tüm göstergeler yüzde (0 ya da 100 arası) ya da oran (0 ya da 1 arası) olarak hesaplanmaktadır. Bir ülkenin EDI değerinin yüksekliği EFA amaçlarının başarma derecesini ve hedefe ulaşma düzeyini göstermektedir (UNESCO, 2005, s.236).

\section{YÖNTEM}

Bu çalışmada Herkes İçin Eğitim 2015 hedefleri çerçevesinde Türkiye'nin 2000-2015 dönemindeki eğitim politika ve uygulamalarının değerlendirilmesi amaçlanmıştır. Nitel araştırma yaklaşımının benimsendiği bu çalışmada, verilerin analizinde doküman incelemesi tekniği kullanılmıştır. Doküman incelemesi, hedeflenen olgu veya olgulara yönelik bilgi içeren yazılı materyallerin analizini kapsamaktadır (Yıldırım ve Şimşek, 2011, s.187). Araştırma kapsamında EFA'nın altı hedefi ile ilgili makale, tez, kitap, ulusal ve uluslararası raporlar incelenmiş, elde edilen veriler sistematik bir şekilde bütünleştirilmeye çalışılarak Türkiye'nin EFA 2015 dönemindeki gelişimine yönelik değerlendirmeler yapılmıştır ve geleceğe ilişkin önerilerde bulunulmuştur.

\section{BULGULAR}

\subsection{Erken Çocukluk Bakımı ve Eğitimi}

İnsanın ilk eğitimi, doğumundan itibaren ailesi ve çevresinde kendiliğinden başlamaktadır. Bireyin kurumsal ve belirli bir program çerçevesinde yapılandırılmış olarak karşılaştığı ilk eğitim kademesi erken çocukluk eğitimidir (EÇE). Herkes İçin Eğitim hareketinin ilk amacı "özellikle en güçsüz ve dezavantajlı çocukları gözeterek, erken çocukluk bakımı ve eğitiminin iyileştirilmesi ve yaygınlaştırılması" olarak belirlenmiştir (UNESCO, 2000). Erken çocukluk eğitimi kavramı, literatürde çocuğun 0-6 yaş dönemini hatta doğum öncesini de kapsayacak şekilde kullanılmakta iken Türkiye'deki yasal düzenlemelerde bu dönem için referans yaş aralı̆̆ı 36-66 ayı kapsamakta ve okul öncesi eğitim kavramı kullanılmaktadır (MEB, 2014a). 
Erken çocukluk dönemi, çocuğun zihinsel, fiziksel ve motor gelişimlerinin en hızlı olduğu bir dönemdir. Bu dönemin önemine ilişkin en temel kanıtlardan birisi, erken yaşlardaki çocuklara yapılan yatırımın, hayatın ileriki safhalarında yapılan yatırımlara kıyasla ekonomik açıdan çok daha verimli olmasıdır. (Dünya Bankası, 2013, s.15). Ayrıca yapılan çeşitli araştırmalar erken çocukluk eğitiminin ilerideki eğitim kazanımları üzerinde, bilişsel gelişimin yükselmesi, daha yüksek akademik başarı ve okul mezuniyet oranlarının artması gibi çeşitli önemli etkileri olduğu bulunmuştur (Heckman \& Cunha, 2007). TüsiAD 2005 yılında yayınladı "Doğru Başlangıç: Türkiye'de Okul Öncesi Eğitim" adlı raporunda başarılı ve topluma faydalı bireylerin yetiştirilmesi için eğitimin mümkün olduğunca erken başlamasını ve örgün eğitime başlangııın bireyin hayatındaki kritik önemine dikkat çekmiştir (TÜSIAD, 2005).

Türkiye'de okul öncesi eğitim, anaokulu ya da anasınıflarında verilmektedir. Anaokulu, 36-66 aylık çocukların eğitimi amacıyla açılan okulu, ana sınıfı ise 48-66 aylık çocukların eğitimi amacıyla örgün ve yaygın eğitim kurumları bünyesinde açılan sınıfı ifade etmektedir (MEB, 2014a). Bu okul ve sınıflar Milli Eğitim Bakanlığı, Sosyal Hizmetler ve Çocuk Esirgeme Kurumu ve özel sektör kuruluşları tarafından açılabilmektedir. Kamu ya da özel sektör tarafından açılan okul öncesi eğitim kurumlarında tam ya da yarım gün eğitim verilebilmekte; yemek ve temizlik harcamaları dışında kamu okulları ücretsiz, özel olanlar ise ücretlidir (Dünya Bankası, 2011, s.9)

EÇE, Türkiye'de özellikle 2005'ten sonra ulusal düzeyde öncelik verilen bir politika alanı olmaya başlamıştır. Bu kapsamda 2007-2013 yıllarını kapsayan 9. Kalkınma Planı'nda EÇE'ye ilişkin hedefler şu şekilde belirlenmiştir: Okul öncesi çocukların eğitimini yaygınlaştırmak amacıyla, öğretmen ve fiziki altyapı gereksinimleri karşılanacak, eğitim hizmetleri çeşitlendirilecek, halkın bilinçlenmesi daha yüksek bir seviyeye getirilecek, erken çocukluk döneminde eğitime ilişkin duyarlılık arttırılacaktır. Ayrıca Türkiye'deki en büyük eğitim sunucusu olan Milli Eğitim Bakanlığı 2010-2015 dönemini kapsayan stratejik planında okulöncesi eğitimde net okullaşma oranının plan dönemi sonuna kadar \% 70'in üstüne çıkarılması amaçlanmış ve yaygınlaştırma sürecinde dezavantajı çocukların erişiminin dikkate alınacağını ifade edilmiştir (MEB, 2009).

MEB belirlenen hedeflere ulaşabilmek için birçok kurum, kuruluş ve STK'lar ile işbirliği yaparak okul öncesi eğitim alanında çeşitli proje ve uygulamalar gerçekleştirmiştir. Bakanlık öncelikle okul öncesi eğitimde okullaşma oranı yüksek olan 32 ilde 60-72 ay yaş grubunda evrensel okul öncesine ulaşmak için 2009 yılında bir pilot program başlatmıştır. Her yıl programın kapsamındaki iller arttırılmıştır. Bununla birlikte dezavantajlı çocukların ve ailelerinin gündüz çocuk bakım ve okulöncesi eğitime kayıt ve devamlarını artırmak için MEB Temel Eğitim Genel Müdürlüğü, Avrupa Birliği ve UNICEF'in desteğiyle "Okulöncesi Eğitimin Güçlendirilmesi" projesini 2010 yılında başlatmıştır. Bu çalışmalara ek olarak Kamu, özel ve STK'ların işbirliğinde okul öncesi eğitime erişimi arttırmak için Erken Çocukluk Eğitimi Projesi, Okul Öncesi Eğitimden İlköğretime Geçiş Projesi, Okul-Veli-Çocuk Eğitim Programı ve Mobil Ana Okulu Projesi gibi çeşitli çalışmalar gerçekleştirilmiştir.

Okulöncesi eğitimi erişimi arttırmaya yönelik yapılan çalışmaların etkisi okullaşma oranına yansımış; 2002 yılında \% 7,5 olan net okullaşma oranı 2012'de \% 30,9'a ve 2015 yııında ise \% 37,12'ye yükselmiştir (MEB, 2015; AÇEV-ERG, 2013). EFA amaçlarının açıklandığı 2000 yılından eylem döneminin sonu olan 2015 yılına kadarki dönemde Türkiye'nin Okul Öncesi eğitim alanında gösterdiği sayısal gelişmeler aşağıdaki Tablo 2'de verilmiştir. 
Tablo 2

1999-2000 ile 2014-2015 arası Okul Öncesi Eğitimde Sayısal Gelişmeler

\begin{tabular}{cccc}
\hline Öğretim Yılı & Okul Sayısı & Öğrenci Sayısı & Öğretmen Sayısı \\
\hline $\mathbf{1 9 9 9 - 2 0 0 0}$ & 8.571 & 213.944 & 15.696 \\
\hline $\mathbf{2 0 0 0 - 2 0 0 1}$ & 9.249 & 258.706 & 16.563 \\
\hline $\mathbf{2 0 0 4 - 2 0 0 5}$ & 15.978 & 434.771 & 22.152 \\
\hline $\mathbf{2 0 0 5 - 2 0 0 6}$ & 18.539 & 550.146 & 20.910 \\
\hline $\mathbf{2 0 0 9 - 2 0 1 0}$ & 26.681 & 980.654 & 42.716 \\
\hline $\mathbf{2 0 1 0 - 2 0 1 1}$ & 27.606 & 1.115 .818 & 48.330 \\
\hline $\mathbf{2 0 1 4 - 2 0 1 5}$ & 26.972 & 1.156 .661 & 68.038
\end{tabular}

Kaynak: MEB (2015). Millî Eğitim İstatistikleri, Örgün Eğitim 2014/'15. s.14. Ankara.

Tabloya göre 2000-2001 yılında Türkiye'de toplam 9.249 okulda 16.563 öğrenci okul öncesi eğitim görürken bu değerler 2015 yılında 26.972 okulda 1.156 .661 öğrenciye yükselmiştir. Bu dönem öğrenci sayılarında beş kat bir artış anlamına gelmektedir. Fakat çağ nüfusunun büyük bir kısmı hala bu eğitim hizmetinden yararlanamamaktadır. Okul öncesi eğitime erişim noktasında Türkiye ve bazı gelişmiş ülkelerin 3, 4 ve 5 yaş okullaşma oranları Tablo 3'te verilmiştir.

Tablo 3

Türkiye ve Çeşitli Ülkelerdeki Erken Çocukluk Eğitiminde Okullaşma Oranları 2013 yılı (3, 4 ve 5 yaş)

\begin{tabular}{lccc}
\multicolumn{1}{c}{ Ülkeler } & $\mathbf{3}$ yaş, $\%$ & $\mathbf{4}$ yaş, $\%$ & $\mathbf{5}$ yaş, \% \\
\hline Almanya & 92 & 96 & 98 \\
\hline Birleşik Krallık & 97 & 96 & 97 \\
\hline Danimarka & 96 & 97 & 99 \\
\hline Finlandiya & 68 & 75 & 100 \\
\hline Fransa & 100 & 100 & 99 \\
\hline Hollanda & 83 & 100 & 97 \\
\hline İspanya & 96 & 97 & 74 \\
\hline Türkiye & 7 & 36 &
\end{tabular}

Kaynak: OECD (2015). Education at a Glance 2015: OECD Indicators. s.333. Paris: OECD.

Tablo 3 incelendiğinde Türkiye'nin erken çocukluk eğitiminde ulaştığı seviyenin gelişmiş ülkelerin çok gerisinde kaldığı görülmektedir. Özellikle Fransa, Danimarka ve Birleşik Krallık gibi ülkelerdeki okullaşma oranları her üç yaş grubu için \% 100 seviyelerindedir. Gelişmiş ülkelerin her yaş grubu için okullaşma oranları bariz bir şekilde Türkiye'nin çok üstünde bulunmaktadır. Bu veriler Türkiye'nin EFA'nın birinci hedefine ulaşılmadı̆̆ını göstermektedir.

Öğrenme doğum ile başlamakta, doğumdan ilkokul başlangıcına kadar olan dönemin çocuğun gelişimi ve büyümesi için çok kritik süreç olduğu dünya genelinde kabul edilmektedir. (UNESCO, 2002, s:38). Türkiye'de son 15 yıl içinde erken çocukluk eğitiminde önemli gelişmeler sağlanmışsa da hala bu eğitime katılım OECD ülkelerine oranla düşük seviyede bulunmaktadır. Örneğin 3 yaşındaki çocukların okul öncesine erişim oranı Türkiye'de \% 7 iken OECD ortalaması $\%$ 74; 4 yaş grubu için oranlar sırasıyla \% 36 ve \% 85'tir (OECD, 2015, s.333). Ayrıca bazı illerde bu eğitim kademesine katılım yüksek olmasına rağmen diğerlerinde oldukça düşüktür. Bu durum okul öncesine katılımın hem yaş grupları hem de ülke genelindeki dağılımı açısından bir 
dengesizliğin olduğunu göstermektedir. Türkiye sonraki dönemde okul öncesi eğitime daha fazla önem vermelidir. Dünya Bankası, "Türkiye'de temel eğitimde kalite ve eşitliğin geliştirilmesi: zorluklar ve seçenekler" adlı raporunda okul öncesi eğitimin kapsamının ve kalitesinin geliştirmesine yönelik olarak Türkiye'de başvurulması gereken bazı politika seçeneklerini belirtmiştir. Bunlar; erken çocukluk eğitiminin genişletilmesiyle ilgili açılımın sonraki aşamalarının düzenlenmesi, kamu ve özel sektör tarafından sağlanan erken çocukluk eğitimi için bir kalite güvence çerçevesinin oluşturulması ve erken çocukluk eğitiminin önemini vurgulayan bilgi kampanyalarının yaygınlaştırılmasıdır (Dünya Bankası, 2011, s.xi).

\subsection{Evrensel İlköğretim / Temel Eğitim}

Binyıllık Kalkınma Hedefleri kapsamında da yer alan evrensel ilköğretim, EFA'nın en önemli amacıdır (UNESCO, 2015, s.77). Dakar Eylem Planı çerçevesinde evrensel ilköğretim hedefi, "2015 yılına kadar tüm çocukların, özellikle kızların, güç koşullar altındaki ve etnik azınlıklara mensup çocukların, ücretsiz ve iyi kalitede bir zorunlu eğitime erişimlerinin ve bu eğitimi tamamlamalarının sağlanması" şeklinde ifade edilmiştir (UNESCO, 2000).

Illköğretime erişim konusu, Türkiye Cumhuriyetin kuruluşundan 21. Yüzyılın ilk yıllarına kadar ülkenin eğitim politikalarının en önemlisi olmayı sürdürmüştür. Cumhuriyetin kuruluşundan sonra yayımlanan anayasa ve kanunlarda ilköğretim zorunlu olduğu belirtilmiş fakat vatandaşların tamamının bu eğitimden faydalanması pratikte uzun yıllar sağlanamamıştır. 1961 yılında çıkarılan 222 Sayılı Illköğretim ve Eğitim Kanunu'nda zorunlu eğitimin 8 yıl olduğu ve 7-14 yaşlarını kapsadığı belirtilmiştir. Bu kanunda ilk kez ilköğretim "temel eğitim" olarak adlandırılarak, eğitimin 5 yılının ilkokulda, geri kalan 3 yılının da tamamlayıcı kurs ve sınıflarda yapılacağı belirtilmiştir. Fakat kanunun getirdiği temel eğitim, 5 yıllık ilkokul olarak uygulanmıştır (Bilasa, 2012, s.71). 1997 yılında çıkarılan 4306 sayılı kanun ile 5 (ilkokul) + 3 (ortaokul) yıl şeklinde devam eden temel eğitim süresi, zorunlu ve kesintisiz olarak 8 yıla çıkarılmıştır (Gündüz, 2011). Temel eğitimde yapılan en son değişiklik 2012 yılında gerçekleştirilen $4+4+4$ düzenlemesi ile gerçekleşmiştir. Bu düzenlemeye göre temel eğitim iki parçaya bölünmüş ve 4 yıl ilkokul 4 yıl ortaokul olarak düzenlenmiştir.

Türkiye'de öğrenim çağında bulunan kız ve erkek çocuklar için mecburi ve devlet okullarında parasız olan mecburi ilköğretim çağı 6-13 yaş grubundaki çocukları kapsamaktadır (222 Sayılı Kanun, Madde 2 ve 3 - (Değişik: 30.3.2012 - 6287/1 md.). Aynı kanunun 7. Maddesinde, ilköğretim; dört yıl süreli ve zorunlu ilkokul ile dört yıl süreli ve zorunlu ortaokuldan oluşan bir Milli Eğitim ve Öğretim Kurumudur denilmektedir (Madde 7 - (Değişik: 30.3.2012 - 6287/2 md.).

Ilköğretimin geliştirilmesi ve yaygınlaştırılması için bu dönemde yapılan en önemli projelerden birisi Temel Eğitime Destek Projesidir (TEDP). Avrupa Birliği Akdeniz Programı kapsamında hazırlanan TEDP, 2002 yılında uygulamaya konulmuştur. Projenin uygulama süresi beş yıldır. Bu projeyle, kırsal kesimde, kentlerde ve gecekondu bölgelerinde en dezavantajlı kesimin yaşam koşullarının iyileştirilmesi; temel eğitimin dışında kalmış çocukların, gençlerin, yetişkinlerin temel eğitim kapsamına alınması; eğitimin niteliğinin artırılması, özellikle kız çocuklarının ve kadınların örgün ve yaygın eğitime erişimlerindeki engellerin ortadan kaldırılması amaçlanmıştır (MEB, 2007a, s. 2-5).

2003 yılında okul dışında kalan çocukları okula döndürmek amacıyla başlatılan diğer önemli bir proje, Haydi Kızlar Okula Kampanyası'dır. Kampanya MEB ile UNICEF işbirliğinde ilköğrenim çağında olup, erkeklere oranla dezavantajlı durumda bulunan kız çocuklarının okullaşmasına destek amacıyla 2003 yılında Ağrı, Batman, Bitlis, Diyarbakır, Hakkâri, Muş, Siirt, Şanlıurfa, Şırnak, Van illerinde başlatılmışır. Projeye, İçişleri Bakanlığı, Sağlık Bakanlığı, Tarım ve Köy İşleri Bakanlığı, Çalışma ve Sosyal Güvenlik Bakanlığı, Diyanet İşleri Başkanlığı, SHÇEK 
kampanyaya destek vermiştir (Bilisa, 2012, s.124). 2003-2004 öğretim yılından itibaren Illköğretim Öğrencilerine Ücretsiz Ders Kitabı Temini Projesi başlatılmıştır. Bu proje kapsamında, ücretsiz dağıtılan tüm ilköğretim öğrencilerinin kitapları MEB tarafından sağlanmış, öğretmenlere de ücretsiz kitap verilmiştir (MEB, 2005, s.17).

Kurumların ve hayırsever vatandaşların eğitime yapacakları katkıları teşvik etmek amacıyla Eğitime Yüzde Yüz Destek Kampanyası başlatılmıştır. Kampanya ile devlet, özel kesim ve sivil toplum örgütleri üçlüsünün el ele vererek ülkenin çeşitli bölgelerinde okul binaları yapılarak öğrencilerin eğitime erişimleri kolaylaştırılmıştır. Bu çalışmalara ek olarak dönem içinde Biz Büyüyoruz Türkiye Büyüyor Projesi, Gönüllü Eğitime Destek Projesi, Temizlik ve Hijyen Eğitimi Projesi, Baba Beni Okula Gönder kampanyası, YіBO Destek Projesi ve Çocuk Dostu Okul Projesi gibi birçok proje yürütülmüştür (MEB, 2006a).

Türkiye için eğitim politikalarında ilköğretime erişim kuruluşundan günümüze kadar önemini korumuş bir öncelik alanı olmuştur. Türkiye'nin 2000 yılından, 2015 yılına kadarki dönemde ilköğretimde sağlanan nicel ilerlemeler Tablo 4'te verilmiştir.

Tablo 4

1999-2000 ile 2014-2015 arası Ilköğretimde Gerçekleşen Sayısal Gelişmeler Illköğretim Net Okullaşma Oranları, \%

\begin{tabular}{cccc}
\hline Öğretim Yılı & Toplam & Erkek & Kız \\
\hline $\mathbf{1 9 9 9 - 2 0 0 0}$ & 93,54 & 98,41 & 88,45 \\
\hline $\mathbf{2 0 0 0 - 2 0 0 1}$ & 95,28 & 99,58 & 90,79 \\
\hline $\mathbf{2 0 0 4 - 2 0 0 5}$ & 89,66 & 92,58 & 86,63 \\
\hline $\mathbf{2 0 0 5 - 2 0 0 6}$ & 89,77 & 92.29 & 87,16 \\
\hline $\mathbf{2 0 0 9 - 2 0 1 0}$ & 98,17 & 98,47 & 97,84 \\
\hline $\mathbf{2 0 1 0 - 2 0 1 1}$ & 98,41 & 98,59 & 98,22 \\
\hline \multicolumn{2}{c}{ ilkokul (Ortaokul) Net Okullaşma Oranları, \% } \\
\hline $\mathbf{2 0 1 4 - 2 0 1 5}$ & $96,30(94,35)$ & $96,04(94,39)$ & $96,57(94,30)$ \\
\hline
\end{tabular}

Kaynak: MEB (2015). Millî Eğitim istatistikleri, Örgün Eğitim 2014/'15. s.1. Ankara.

Tablo 4'e göre Türkiye'de 1999-2000 öğretim yılında ilköğretimde toplam net okullaşma oranı 93,54'tür. Bu oran erkeklerde \% 98,41 iken kızlarda \%88,45 olarak gerçekleşmiştir. 2000 yıında okullaşma oranı açısından kızlar aleyhine $\% 10$ düzeyinde bir fark görülmektedir. Okullaşma oranlarındaki kız ve erkek açısından bu fark her geçen yıl azalarak 2009-2010 öğretim yılında hemen hemen eşit seviyeye gelmiştir. Bu veri Türkiye'nin ilköğretimde cinsiyet eşitliğini sağladığını göstermektedir. Eylem planının sonu olan 2015 yılı açısından verilere baktığımızda cinsiyet eşitliğinin hem ilkokul hem de ortaokul düzeyinde sağlandığını fakat hala okul çağında olup da eğitime erişimi sağlanamamış bireylerin olduğu görülmektedir. Yaklaşık olarak ilkokul için \% 4'lük, ortaokul için ise \% 6'lık bir kayıp vardır.

Herkes İçin Eğitim Gelişim İndeksi kapsamında ilköğretimde evrenselleşme hedefi, net okullaşma oranı göstergesine göre değerlendirilmektedir. Bu gösterge kapsamında her kesimden tüm çocukların kaliteli eğitime erişimlerinin sağlanması gerekmektedir. Türkiye'nin okullaşma oranı 2014-15 öğretim yılında ilkokul için \% 96,30, ortaokul için \% 94,35 olarak gerçekleşmiştir. Türkiye, evrensel ilköğretim hedefine çok yaklaşmasına rağmen hedefin altında kalmıştır. Bununla birlikte evrensel ilköğretimin gerçekleştirilip gerçekleştirilmediği yalnızca katııı ile değil, aynı zamanda çocukların ilköğretimi tamamlayıp tamamlamadıklarına göre de değerlendirilmektedir (UNESCO, 2014, s.3). Göstergenin bu boyutu da dikkate 
alındığında Türkiye'nin istenen düzeyden biraz daha aşağıda olduğu söylemek doğru olacaktır. 2015 sonrası dönemde temel eğitimin dışında kalmış bireylere ve okula devam sıkıntısı olan öğrencilere yönelik olarak özel proje ve politikaların uygulanması gerekmektedir.

\subsection{Genç ve Yetişkin Beceriler}

Günümüzün hızla değişen dünyasında bireylerin eğitim ihtiyaçları da sürekli artmaktadır. Temel eğitim sonrasında gençliğe ilk adımlarını atan bireylerin öğrenme ihtiyaçlarının karşılanması ve iş hayatında ihtiyaç duyacakları beceriler ile donatılması önemli bir politika alanı olmayı sürdürmektedir. Bu nedenle EFA'nın üçüncü amacı "Tüm genç ve yetişkinlerin, uygun öğrenme ve yaşam becerileri programlarına eşitlik içinde erişimleri sağlanarak, öğrenme gereksinimlerinin karşılanması" şekilde ifade edilmiştir (UNESCO, 2000). EFA kapsamında, öğrenme okul çağı ya da herhangi bir yaş ile sınırlandırılmaması gereken bir faaliyet olarak görülmekte, yaşam becerileri ise sürdürülebilir bir hayat için gerekli olan ve bireyin topluma katılımı sağlayan beceriler olarak belirtilmektedir (UNESCO, 2002, s.56-57).

Gençler ve yetişkinler için her türlü öğrenme fırsatlarına erişimlerinin sağlanması, onların iş kapasitelerinin geliştirmelerine, topluma katılımlarının kolaylaşmasına, kendi yaşamlarına kontrol edebilmeleri ve öğrenmeye devam etmelerine imkân sağlayacaktır (UNESCO, 2002, s.56). Bu amaç kapsamında tüm ülkeler genel ve mesleki ortaöğretime katılımı arttıracak politikalar gerçekleştirmekte, okul dışındaki bireylere de yaygın eğitim kapsamında eğitim hizmetine erişimlerine yönelik olarak yasal ve yapısal değişiklikler yapmaktadır.

Bireylerin potansiyellerini gerçekleştirmeleri ve toplumsal hayata etkin bir şekilde katılabilmeleri için ortaöğretim çağında kazanılacak bilgi, beceri ve yetkinliklere (bilişim okuryazarlığı, yabancı dil, üst düzey eleştirel düşünme becerileri, vb.) gereksinimleri artmaktadır (ERG, 2012, s.12). Buna rağmen, ortaöğretim Türkiye'deki eğitim kademeleri arasında en sorunlu alanlardan birisi olmayı sürdürmektedir. Çengel (2009), eğitim sistemimizdeki misyonsuzluk örneği olarak lise eğitimini göstermekte; lisenin mezunlarını gerçek hayata hazırlamadığını, mevcut sınav siteminin baskısı nedeni ile öğrencilere gerçek hayatta hiçbir karşılığı olmayan test çözme becerilerinin öğretildiği bir kurum olduğunu belirtmektedir.

2000 yılından günümüze ortaöğretim birçok yasal, yapısal ve programlar açısından değişikliklerin yapıldığı bir alan olmuştur. Yasal açıdan 2012 yılında yapılan değişiklik ile ortaöğretimin zorunlu eğitim kapsamına alınarak süresinin üç yıldan dört yıla çıkarılması en önemli değişikliktir. Kamuoyunda $4+4+4$ sistemi olarak bilinen bu değişiklik ile ortaöğretimde net okullaşma oranlarında yükseliş gerçekleşmiştir. 2012-13 eğitim-öğretim yılında \% 70,06 olan okullaşma oranı, 2013-14'te \% 76,65'e yükselmiştir. Ancak, Türkiye genelinde okullaşma oranlarındaki eşitsizlik devam etmekte ve iller bazında ciddi farklılıklar bulunmaktadır (ERG, 2013, s.47). Türkiye'nin 2000 yılından, 2015 yılına kadarki dönemde ortaöğretimde gerçekleşen okullaşma oranları Tablo 5'te verilmiştir.

Tablo 5

1999-2000 ile 2014-2015 arası Ortaöğretimde Okullaşma Oranları

Ortaöğretim Net Okullaşma Oranları, \%

\begin{tabular}{cccc}
\hline Öğretim Yılı & Toplam & Erkek & Kız \\
\hline $\mathbf{1 9 9 9 - 2 0 0 0}$ & 40,38 & 44,05 & 36,52 \\
\hline $\mathbf{2 0 0 0 - 2 0 0 1}$ & 43,95 & 48,49 & 39,18 \\
\hline $\mathbf{2 0 0 4 - 2 0 0 5}$ & 54,87 & 59,05 & 50,51 \\
\hline $\mathbf{2 0 0 5 - 2 0 0 6}$ & 56,63 & 61,13 & 51,95
\end{tabular}




\begin{tabular}{llll}
\hline $\mathbf{2 0 0 9 - 2 0 1 0}$ & 64,95 & 67,55 & 62,21 \\
\hline $\mathbf{2 0 1 0 - 2 0 1 1}$ & 66,07 & 68,17 & 63,86 \\
\hline $\mathbf{2 0 1 4 - 2 0 1 5}$ & 79,37 & 79,46 & 79,26 \\
\hline
\end{tabular}

Kaynak: MEB (2015). Millî Eğitim Istatistikleri, Örgün Eğitim 2014/'15, s.1. Ankara.

Tablo 5'e göre 1999-2000 öğretim yılında ortaöğretim çağında bulunan her 100 bireyden 40'ı okulda iken bu sayı 2004-2005'te 54'e, 2009-2010'da 64 ve 2015 yılında 79'a yükselmiştir. Başlangıç noktasına göre okullaşma oranı 15 yıllık süreçte iki katına yükselmiştir. Türkiye açısından önemli bir başarı olan bu gelişmenin yanında ortaöğretimde cinsiyet eşitliği 2015 yılında sağlanmıştır. Illköğretimde olduğu gibi ortaöğretim düzeyinde de Türkiye, cinsiyet eşitsizliği problemini EFA'nın bu döneminde gidermiştir.

Türkiye'nin uzun yıllardır politik bir hedef olarak belirlediği bir konu da mesleki eğitimin ortaöğretim içindeki payıdır. Mesleki ve teknik eğitime katılımın arttırılması için kamu, özel sektör ve STK'lar tarafından çeşitli çalışma ve projeler yürütülmüştür. Bu projelerden en önemlisi 2006-2011 yıllarında gerçekleştirilmiş olan Ortaöğretim Projesidir. Dünya Bankası'nın mali desteğiyle gerçekleştirilen projede genel ve mesleki ve teknik ortaöğretim sisteminin yeniden yapılandırılması, kalitesinin artııılması, öğretim programlarının geliştirilmesi, yenilenen programlara göre öğretmenlerin eğitilmesi ve eğitim ortamlarının donatılması amaçlanmıştır (ERG, 2012, s.33). Bu çalışma kapsamında ortaöğretimdeki öğretim programları çağın ihtiyaçları doğrultusunda güncellenmiştir. Diğer önemli bir proje mesleki eğitim ve öğretim sisteminin sosyoekonomik gereksinimler ve hayat boyu öğrenme ilkeleri doğrultusunda güçlendirilmesi amacıyla yürütülen ve Avrupa Komisyonu tarafından desteklenen Mesleki Eğitimi Geliştirme Projesidir (MEGEP). 2002-2007 arasında yürütülen projede 31 ilde yapılan ihtiyaç analizlerine göre Türkiye'deki işgücü piyasalarına ilişkin bilgi toplanmıştır. Mesleki eğitime yönelik olarak yapılan önemli projelerden biriside, Meslek Lisesi Memleket Meselesi adlı projedir. Tablo 6'te genel ve mesleki-teknik ortaöğretimdeki öğrenci oranlarını verilmiştir.

Tablo 6

2004-2005 ile 2014-2015 arası Ortaöğretimde Öğrenci Oranları

Ortaöğretim Türüne Göre Öğrenci Oranları, \%

\begin{tabular}{lcc}
\hline Öğretim Yılı & Genel Orta Öğretim & Mesleki ve Teknik Ortaöğretim \\
\hline $\mathbf{2 0 0 4 - 2 0 0 5}$ & 63,8 & 36,2 \\
\hline $\mathbf{2 0 0 5 - 2 0 0 6}$ & 63,8 & 36,2 \\
\hline $\mathbf{2 0 0 9 - 2 0 1 0}$ & 57,1 & 42,9 \\
\hline $\mathbf{2 0 1 0 - 2 0 1 1}$ & 56,4 & 43,6 \\
\hline $\mathbf{2 0 1 4 - 2 0 1 5}$ & 57,8 & 42,2
\end{tabular}

Kaynak: MEB (2015). Millî Eğitim Istatistikleri, Örgün Eğitim 2014/'15. s.124. Ankara.

ERG (2012). Meslek Eğitiminde Kalite İçin İşbirliği Mesleki Ve Teknik Eğitimde Güncellenmiş Durum Analizi. s.20. İstanbul: Eğitim Reformu Girişimi.

Tablodaki verilere göre Türkiye'de mesleki ve teknik ortaöğretime olan talep azda olsa artmaktadır. 2004-2005 öğretim yılında mesleki ve teknik öğretimdeki öğrenci oranı \% 36,2 düzeyinde iken 2009-2010'da \% 42,6'ya ve 2015 yılında ise biraz düşerek \% 42,2 düzeyine inmiştir. Mesleki ve teknik ortaöğretimde 10 yıllık süreç içinde $\% 6^{\prime}$ lık bir oran artışı gerçekleşmiştir.

1739 sayılı Milli Eğitim Temel Kanunu'na göre Türkiye eğitim sistemi örgün ve yaygın eğitim olmak üzere iki ana bölümden oluşmaktadır. Yaygın eğitim, örgün eğitim yanında veya 
dışında düzenlenen eğitim faaliyetlerinin tümünü kapsamaktadır (METK, madde 18). Türkiye'de yaygın eğitim faaliyetleri hayat boyu öğrenme (HBÖ) kapsamında değerlendirilmektedir. 2000'li yılların başından itibaren yaygın eğitim alanının genel çerçevesi ve istikametini Avrupa Birliği'nin dokümanları belirlemektedir. Türkiye bu çerçevede 2006 yılında yaygın eğitim sektörünü de içine alan Türkiye'nin Başarısı için İtici Güç: Hayat Boyu Öğrenme politika belgesini hazırlamıştır. Bu belgede hayat boyu öğrenme, "kişisel, sosyal ve/veya mesleki nedenlerden dolayı bilgi, beceri ve yetkinliklerin arttırılmasına yönelik olarak hayat boyunca gerçekleştirilen tüm öğrenme faaliyetler" olarak tanımlanmaktadır (MEB, 2006b). Politika belgesi sonrasında özellikle yaygın eğitimde önemli değişimler öngören Türkiye Hayat Boyu Öğrenme Strateji Belgesi uygulamaya konmuştur. 2009-2013 yıllarını kapsayan bu belge, okul öncesinden yaşlıların eğitimine, mevzuat düzenlenmesinden eğitimin finansmanına kadar eğitim/öğretim ile ilgili bütün konuları kapsamaktadır. (MEB, 2014b). 2014 yılında ilk belgenin devamı niteliğinde olan ikinci 5 yıllık dönemi kapsayan strateji belgesi hazırlanarak uygulanmasına başlanmıştır. 2014-2018 dönemini içeren belge 6 temel öncelik alanı belirlemiştir. Bunlar, toplumda HBÖ kültürü ve farkındalığının oluşturulması, HBÖ fırsatlarının ve sunumunun artırılması, HBÖ fırsatlarına erişimin artırılması, hayat boyu rehberlik ve danışmanlık sisteminin geliştirilmesi, önceki öğrenmelerin tanınması sisteminin geliştirilmesi, HBÖ izleme ve değerlendirme sisteminin geliştirilmesidir (MEB, 2014b).

Yaygın eğitim çerçevesinde Türkiye'de MEB bünyesinde oluşturulan kurumsal yapının coğrafi dağılımının yaygınlığı, sunulan genel ve mesleki-teknik eğitim programlarının çeşitliliği ve ücretsiz olması genç ve yetişkin bireylerin öğrenme fırsatlarına erişimini kolaylaştırarak yaşam becerilerini edinmelerine imkân sağlamaktadır. Bu kapsamda, Milli Eğitim Bakanlığına bağlı toplam 1.343 yaygın eğitim kurumu ile Türkiye'nin tüm il ve ilçelerinde 987 halk eğitimi merkezi, 332 meslekî eğitim merkezi, 15 olgunlaşma enstitüsü, 10 turizm eğitim merkezi ile hayat boyu öğrenme faaliyetleri desteklenmektedir. Hayat boyu öğrenme faaliyetleri kapsamında uygulanan kurs programları 2007 yılında 321 olan kurs programı sayısı 2015 yılı itibarıyla 2.272'ye çıkmışır. Yaygın eğitim kurumlarından 2013-2014 öğretim yılı sonunda toplam 6.667.164 kişi faydalanmıştır (MEB,2015, s.215).

Genç ve yetişkin beceriler açısından Türkiye'nin 15 yıllık dönemine bakıldığında ortaöğretim düzeyinde okullaşma oranlarında önemli bir artışın olduğu, cinsiyet eşitliğinin sağlandığını, yaygın eğitim açısından program çeşitliliğinin sağlandığını söyleyebiliriz. Fakat ortaöğretimde zorunlu eğitime geçilmesine rağmen tüm bireylerin eğitime erişiminin sağlanamadığı, ortaöğretimde mesleki eğitimin payının istenen düzeye çıkarılamadığını belirtmek gerekir. MEB'in 2014 sonu stratejik hedeflerinden birisi, ortaöğretim içindeki mesleki ve teknik eğitimin okullaşma oranını \% 50'ye çıkarmak olarak belirlenmişti (MEB, 2009). Bunların yanında hem ortaöğretim hem de yaygın eğitimde kalite problemleri devam etmektedir. Genç ve yetişkin öğrenmeleri kapsamında Türkiye'nin gerçekleştirdiği niceliksel gelişmelere paralel olarak eğitim sistemi nitelikli geliş eğrisini yakalayamamıştır (TEDMEM, 2015). Bu nedenle çok boyutlu bir kavram olan kalitenin istenen düzeye çıkarılabilmesi için tüm eğitim paydaşlarının etkin katılımı ile sorunların gerçek nedenlerinin bilimsel olarak tespit edilmesi, bu doğrultuda rasyonel stratejilerin belirlenmesi ve etkin bir şekilde uygulamaya konulması ülkenin geleceği açısından önemlidir.

\subsection{Yetişkin Okur-yazarlığı}

1990 ve 2000 yıllarında yapılan Herkes için Eğitim toplantılarında bireyin ve toplumun gelişmesi için okuryazarlığın önemi vurgulanmıştır. Bu kapsamda EFA'nın 4. amacı "2015 yılına kadar, başta kadınlar olmak üzere tüm yetişkinler için temel / sürekli eğitime eşit erişim olanağı sağlayarak, yetişkin okuryazarlığı oranını \% 50 düzeyinde yükseltmeyi başarma" şeklinde ifade edilmiştir (EFA, 2000). Günümüzde okuryazarlık kavramı artık tekil bir beceri olarak değil çoklu 
okuryazarlık olarak algılanmakla, okuyabilmek, yazabilmek ve temel matematiksel işlemleri yapabilmek bir insan hakkı olarak kabul edilmektedir (EFA, 2002, s. 60). 2000 yılında Dünya'da \% 18 olan okumaz-yazmazlık oranı 2015'te \% 14'e düşmüş ve bu dönemde gösterilen tüm çabalara rağmen Dünya'da hala 781 milyon okumaz-yazmaz yetişkin bulunmaktadır (EFA, 2015, s.xiii). Bireyin ve toplumların geleceği için önemli olan yetişkin okur-yazarlık düzeyinin gelişimi bu dönem içinde düşük düzeyde kalmıştır.

Türkiye'de okuryazarlık ile ilgili çalışmalar Cumhuriyetin kuruluşuna hatta modernleşme dönemine kadar götürülebilir. Özellikle Cumhuriyet kurulduktan sonra modern Batı dünyasının ulaştığı seviyeye çıkmayı hedef edinmiş olan Türkiye bu kapsamda en önemli adımlardan birisi olan harf inkılabını 1928 yılında gerçekleştirmiştir. O tarihten günümüze toplumun okuryazarlık konusu önemli bir eğitim politikası haline gelmiştir. Cumhuriyetin kuruluş yıllarında yaklaşık \% 10 olan okuryazarlık oranını arttırmak için günümüze kadar 1928, 1960, 1971, 1981, 2001 ve 2007 yıllarında olmak üzere ülke genelinde 6 kitlesel okuma-yazma kampanyası düzenlenmiştir (Yıldız, 2010).

Okuryazarlık becerileri çocukluk dönemindeki kaliteli eğitim yoluyla en iyi şekilde geliştirilebilir (UNESCO, 2013/14, s. 4). Türkiye'de eğitim alanında gerçekleştirilen en önemli projelerden birisi 2002-2007 yıllarında uygulanmış olan Temel Eğitime Destek Projesidir (TEDP). Avrupa Birliği'nin destek verdiği ve MEB tarafından yürütülen proje kapsamında eğitime erişim ve dezavantajlı gruplar, eğitimin kalitesi, eğitimde adil fırsat eşitliği ve yetişkin eğitimi alanlarında çalışmalar yürütülmüştür. Projede özellikle okul çağındaki bireylerin ve dezavantajlı durumdaki vatandaşların temel eğitime erişimleri sağlanmıştır. Bunula birlikte yetişkin okuryazarlığının desteklenmesi TEDP programı için öncelikli bir çalışma alanı olmuştur. Projede yeni yetişkin okuma-yazma programları ve materyallerinin geliştirilmiştir (MEB, 2007a).

MEB'in okuma-yazma alanında gerçekleştirdiği diğer önemli bir çalışma Ulusal Eğitime Destek kampanyasıdır. 2001 yılında ülke genelinde başlatılan bu çalışmanın temel amacı ile okuma-yazma bilmeyen yurttaşların eksik eğitimlerini tamamlamak ve temel eğitim düzeyinde eğitim görmelerine olanak sağlamak, gelir getirici beceri ve meslek kazanmalarını sağlamak, zorunlu eğitim çağında olup okul dışında kalan çocukların okula kazandııımalarını sağlamaktır. 2001 yılından 2007 yılına kadar kampanya kapsamında 1.458 .666 vatandaşımız okuma-yazma kurslarını başarı ile bitirmiştir (http://okuma-yazma.meb.gov.tr/tarihce).

Yetişkin okuryazarlığına yönelik olarak Türkiye'de yapılan önemli bir çalışma 2007 yılındaki yetişkin okuryazarlık programlarının çağın ihtiyaçları doğrultusunda güncellenmesidir. 2000'li yıllarda Türk Eğitim Sistemi'nde ders programlarının (ilköğretim ve ortaöğretim) yeni bir anlayışla geliştirilmesi çalışmalarına ek olarak "Yetişkinler Okuma Yazma Öğretimi ve Temel Eğitim Programı" hazırlanarak yürürlüğe girmiştir. Bu programın amaçları; okuma yazma bilmeyen yetişkinlere işlevsel okuma yazma becerisi kazandırma, ilköğretimin ilk beş sınıfına denk eğitim verme, yetişkinlerin yaşam kalitesini yükseltebilecek bilgi, beceri ve tutum kazandırma ve yetişkinlerin hayat boyu öğrenme fikrini edinmelerini sağlama şeklinde belirtilmiştir (MEB, 2007b, s.2). Hazırlanan bu yeni programın iki ana bileşeni bulunmaktadır. Yetişkinler I. Kademe Okuma Yazma Öğretimi ve Temel Eğitim Programı ile Yetişkinler II. Kademe Eğitimi Eğitim Programı'dır. Birinci bileşen daha çok okuma yazma becerisi ile birlikte yaşam ve matematik becerilerine odaklanmakta diğer bileşen ise ilköğretimin dördüncü ve beşinci sınıf düzeyine denk bilgi, beceri ve tutum kazandırmayı amaçlamaktadır.

Okuma-yazma probleminin çözümüne yönelik olarak ulusal düzeyde 2008-20012 yıllarında arasında gerçekleştirilen önemli bir çalışma ise Ana Kız Okuldayız Kampanyası'dır. Kampanya çerçevesinde öncelikle Bakanlığa bağlı Halk Eğitimi Merkezleri aracılığıyla okuma yazma bilmeyenlerin tespiti yapılmıştır. Kitle iletişim araçları aracılığıyla etkin bir farkındalık 
çalışmaları yürütülmüş ve okuma yazma bilmeyen her birey için okuma yazma kursu açılmıştır. Kampanya süresince ülke genelinde 1. Kademe Okuma Yazma-Kursunu 1.832 .617 kişi, 2. Kademe Okuma-Yazma Kursunu ise 307.364 kişi tamamlamıştır (http://okumayazma.meb.gov.tr/tarihce).

Türkiye'de 2000 yılında okuryazarlık oranı \% 86,5'tir (Yıldız, 2010). EFA 2015 hedeflerinin belirlendiği dönemde ülkede yetişkin nüfusun yaklaşık olarak \% 15'i okuryazar değildir. 2000 yılından günümüze yapılan çeşitli çalışmalar ve yenilikler sonucunda yetişkinlerin okuryazarlık değişimlerini gösteren tablo aşağıda verilmiştir.

Tablo 7

2008-2013 yılları arası +15 Yaş Çağ Nüfusunun Okuma Yazma İstatistikleri

Yıl Nüfus Okuma Yazma Bilmeyen

\begin{tabular}{|c|c|c|c|c|c|c|}
\hline & \multirow[b]{3}{*}{ Genel } & \multirow[b]{3}{*}{ +15 Yaş } & \multirow{2}{*}{\multicolumn{2}{|c|}{ Toplam }} & \multirow{3}{*}{$\begin{array}{c}\text { Erkek } \\
\text { Sayı }\end{array}$} & \multirow{3}{*}{$\begin{array}{c}\text { Kadın } \\
\text { Sayı }\end{array}$} \\
\hline & & & & & & \\
\hline & & & Sayı & $\%$ & & \\
\hline 2008 & 71.517 .100 & 52.728 .513 & 4.863 .414 & 9,24 & 1.331 .697 & 3.896 .716 \\
\hline 2009 & 72.561 .312 & 53.701 .978 & 4.645 .638 & 8,68 & 908.628 & 3.737 .010 \\
\hline 2010 & 73.722 .988 & 54.844 .406 & 3.812 .092 & 6,97 & 697.305 & 3.114 .787 \\
\hline 2011 & 74.724 .269 & 55.837 .694 & 3.163 .396 & 5,69 & 551.776 & 2.611 .620 \\
\hline 2012 & 75.627 .384 & 56.770 .205 & 2.784 .257 & 4,93 & 474.016 & 2.310 .241 \\
\hline 2013 & 76.667 .864 & 57.818 .050 & 2.643 .712 & 4,60 & 443.640 & 2.200 .072 \\
\hline
\end{tabular}

Kaynak: MEB (2014c). 2001-2014 Yılları Arası Yetişkin Okuma Yazma Çalışmaları. http://okumayazma.meb.gov.tr/sites/default/files/sites/default/files/dosyalar/2001-2014.pdf. (Erişim tarihi: 2015, 21 Kasım).

Tabloya göre Türkiye'de 2008 yılında 4.863.414 kişi okuma yazma bilmemekte ve bu grubun çağ nüfusuna oranı \% 9,24'tür. Her geçen yıl çağ nüfusu artmasına rağmen okuma yazma bilmeyenlerin oranı 2013 yılında 2.643.712'ye gerilemiş ve çağ nüfusuna oranı \% 4,60 olmuştur. Bu sonuçlar beş yıllık süreçte okuma yazma bilmeyenlerinin oranının yarıya düştüğünü göstermektedir. Bu verilerde önemli husus okuma yazma bilmeyen grupta kadınların sayısının fazla olmasıdır. 2013 yılında Türkiye'de hala 2.200.072 kadın okuma yazma bilmemektedir.

EFA 2015 döneminde yapılan çeşitli çalışmalar sonucunda 2000 yılında \% 15 civarında olan okuma yazma bilmeyenlerin oranı dönem sonu itibariyle $\% 5^{\prime}$ in altına düşürülmüştür. Bu sonuç yetişkin okuryazarlığı konusunda \% 50'den fazla bir ilerlemenin olduğunu göstermektedir. Buna rağmen 15 ve üstü çağ nüfusunda hala azımsanamayacak sayıda vatandaş bulunmakta ve bunların büyük bir kısmını kadınlar oluşturmaktadır. 2015 sonrası eğitim gündemi kapsamında özellikle kadınların sosyoekonomik statüsü, coğrafi durumu ve eğitimsel geçmişi gibi durumlar gözetilerek hazırlanacak projeler ile tüm çağ nüfusunun okuma yazma becerilerini elde etmesi sağlanabilir. Bununla birlikte yetişkin okuryazarlığının sadece okuma ve yazma çerçevesinde değil de yetişkin bireylerin günümüz dünyasında ihtiyaç duyduğu temel yaşam becerilerini de içine alacak şekilde düşünülmesi ve planlanması da hem birey hem de toplumun geleceği için önemli bir yaklaşım olacaktır.

\subsection{Cinsiyet Eşitliği}

Eğitim, temel bir insan hakkıdır ve bu nedenle hem erkek hem de kadınların eğitim alma imkânları açısından bir eşitsizliğin olmaması tüm toplumlar için gereklidir. Buna rağmen dünya genelinde cinsiyet açısından önemli eşitsizliklerin olduğu ve günümüzde bu eşitsizliğin 
tamamen giderilemediği bir gerçektir. Herkes için eğitim sloganı ile başlayan EFA hareketinin 5. Amacı bu soruna yönelik olarak belirlenmiştir. 5. Amaç şöyle ifade edilmiştir: "2005 yılına kadar ilk ve ortaöğretimde cinsiyet farklılıklarını ortadan kaldırma ve kızların iyi kalitede bir temel eğitime tam ve eşit erişimi ve başarıları üzerinde yoğunlaşarak, 2015 yılına kadar tüm eğitim kademelerinde cinsiyet eşitliğini sağlama"(EFA, 2000). Sorunun öneminden dolayı Birleşmiş Milletler tarafından 2000 yılında başlatılan Bin Yıllık Kalkınma Hedefleri kapsamında cinsiyet eşitsizliklerinin giderilmesi önemli hedeflerden birisi olarak belirlenmiştir. Bin Yıllık Kalkınma Hedefleri'nin 2 ve 3. amaçlarında sırasıyla "2015 yılına kadar dünyanın her yerindeki kız ve erkek çocuklarının ilköğretim hakkından eksiksiz yararlanması" ve "toplumsal cinsiyet eşitsizliğini ilk ve orta öğretimde tercihen 2005 yılına kadar ve eğitimin her düzeyinde 2015 yılına kadar ortadan kaldırmak" olarak ifade edilmiştir (UN, 2000). Küresel düzeydeki bu eğitim hareketlerinin sonucunda 2000 yılından bu yana EFA amaçları arasında en büyük ilerleme cinsiyet eşitliğinde sağlanmıştır (UNESCO, 2015). 2000-2015 yılları arasında her 100 erkek çocuğa karşı kız çocuk sayısı ilköğretimde 92'den 97'ye, ortaöğretimde ise 91'den 97'ye yükselmiştir (EFA, 2015a).

Türkiye açısından eğitim kademelerinde cinsiyet eşitsizliğini gidermeye yönelik en önemli uygulamalar yasal çerçevede yapılan değişikliklerdir. 5 yıl zorunlu olan ilkokul 1997 yılında kesintisiz zorunlu ilköğretim olarak 8 yıla çıkarılmıştır. Bu düzenleme sonucunda \% 94 olan cinsiyet oranı, \% 85,7’ye gerilemiştir. Fakat bu düşüş ortaokul düzeyindeki kızlar aleyhine olan cinsiyet oranlarının etkisinin bir sonucudur (DPT, 2010, s.29). Bu kapsamda yapılan diğer önemli bir düzenleme 2012 yılında gerçekleştirilmiştir. Kamuoyunda 4+4+4 sistemi olarak bilinen değişiklik ile ilköğretim ve ortaöğretim kademeleri 4'er yıl olarak belirlenerek, ortaöğretim zorunlu hale getirilmiştir. Bu iki önemli yasal düzenleme ile örgün eğitim kademelerinde kızların eğitime erişimleri sürekli artış göstermektedir.

Milli Eğitim Bakanlığı tarafından bu konuda gerçekleştirilen diğer çalışmalara ise şunlardır: yatılı ilköğretim bölge okullarının (YIBO) kurulması, okula erişimi coğrafi olarak zor olan kırsal alanlarda yaşayan çocuklar için "Taşımalı İlköğretim Uygulaması"na geçilmesi ve fakir ailelerin çocukları için burs imkânları ve Şartlı Nakit Transferi uygulamasıdır. Bu alanda yapılan önemli projeler ise, ilköğretim okullaşma oranının en düşük olduğu 10 ilde başlatılan ve daha sonra Türkiye geneline yaygınlaştırılan "Haydi Kızlar Okula" ile "Ana Kız Okuldayız Kampanyası'dır.

Türkiye'de eğitimle ilgili çalışmaların değerlendirilmesinde ve kanıta dayalı politikaların geliştirilmesinde en önemli zorluklardan biri sayısal verilerle ilgilidir (TÜSIAD, 2008, s.32). Türkiye'de 2007 yılından itibaren TÜiK tarafından Adrese Dayalı Nüfus Kayıt Sistemi (ADNKS) uygulamaya başlanmıştır. Milli Eğitim Bakanlığı da kendi bünyesinde ADNKS ile uyumlu e-okul sistemi uygulamasına geçmiş ve eğitim dışında kalan çocukların doğru bir şekilde tespit edilmesini sağlayacak veriler elde edilebilmesi önündeki engel kaldırılmıştır. Bu veriler ışığında, bireylerin eğitime erişim daha rahat bir şekilde izlenebilmektedir.

Bu dönem içinde Türkiye'de eğitimi de içine alacak şekilde toplumsal cinsiyet eşitliğini daha büyük perspektiften ele alan Toplumsal Cinsiyet Eşitliği Ulusal Eylem Planı 2008-2013 uygulanmıştır. Nihai hedefi kadına karşı ayrımcılığı önlemek ve kadınların sosyal ve ekonomik konumlarını iyileştirmesini sağlamak olan Eylem Planı ile Türkiye'de 2008-2013 döneminde kadın ve erkeklerin yaşamlarının çeşitli alanlarında toplumsal cinsiyet eşitliğinin geliştirilmesi sağlayacak politikalar belirlenmiştir (Başbakanlık, 2008, s.6).

EFA hedeflerindeki gelişimi izlemek için oluşturulan EFA Gelişim İndeksindeki önemli bir bileşen cinsiyet eşitliği göstergesidir. Cinsiyet eşitliği EFA'nın 2, 3 ve 4 nolu amaçlarının içinde bulunmaktadır. Bu özelliğinden dolayı EFA kapsamında cinsiyet eşitliği göstergesi 
ilköğretim ve ortaöğretimdeki brüt okullaşma oranları ile yetişkin okuryazarlığı oranının aritmetik ortalaması alınarak hesaplanmaktadır (UNESCO, 2005, s.241). Türkiye 2000-2015 dönemindeki yapılan çalışmalar sonucunda cinsiyet oranlarındaki değişim her bir boyut açısından Tablo 8' de verilmiştir.

Tablo 8

Türkiye 2000-2015 Dönemi Illköğretim, Ortaöğretim ve Yetişkin Okuryazarlığı Boyutundaki Niceliksel Gelişmeler (Bazı Yıllara Göre)

Yıl Cinsiyet Oranları

Yetişkin Nüfusun Cinsiyete Göre Okuryazarlık Oranı

\begin{tabular}{|c|c|c|c|c|c|}
\hline & \multicolumn{2}{|c|}{ İlköğretim (8 yıl) } & Ortaöğretim & Erkek & Kadın \\
\hline 2000 & \multicolumn{2}{|c|}{88,54} & 74,74 & 94,42 & 78,50 \\
\hline 2005 & \multicolumn{2}{|c|}{92,33} & 78,72 & $\ldots$ & $\ldots$ \\
\hline 2008 & \multicolumn{2}{|c|}{96,39} & 85,81 & 95,98 & 84,18 \\
\hline 2010 & \multicolumn{2}{|c|}{98,91} & 88,59 & 97,30 & 88,07 \\
\hline \multirow[t]{2}{*}{2011} & \multicolumn{2}{|c|}{100,42} & 89,74 & 97,93 & 90,31 \\
\hline & İlkokul (4 yıl) & Ortaokul(4 yıl) & Ortaöğretim(4 yıl) & & \\
\hline 2013 & 100,59 & 102,94 & 94,15 & 98,45 & 92,36 \\
\hline 2014 & 100,82 & 103,69 & 94,59 & $\ldots$ & $\ldots$ \\
\hline 2015 & 100,57 & 101,10 & 95,40 & $\ldots$ & $\ldots$ \\
\hline
\end{tabular}

Kaynak: MEB (2015). Millî Eğitim Istatistikleri, Örgün Eğitim 2014/'15. s.10. Ankara.

TÜiK (2012). Istatistik Göstergeler 1923-2011, s.19. Ankara.

MEB (2014c). 2001-2014 Yılları Arası Yetişkin Okuma Yazma Çalışmaları, http://okumayazma.meb.gov.tr/sites/default/files/sites/default/files/dosyalar/2001-2014.pdf. (Erişim tarihi: 2015, 21 Kasım).

Tabloya göre Türkiye 2000 yılında 2015 cinsiyet eşitliği alanında önemli gelişmeler sağlamıştır. illköğretimde 2000 yılında \% 88,54 olan oran 2015 yılında \% 100'ü geçmiştir. Hem ilkokul hem de ortaokul düzeyinde cinsiyet eşitsizlikleri giderilmiştir. Ortaöğretim düzeyi açısından da ciddi bir ilerleme söz konusudur. 2015 yılı itibariyle ortaöğretimde cinsiyet oranı \% 95,40 olmuştur. Türkiye'de cinsiyet eşitsizliğinin en belirgin olduğu alan yetişkin okuryazarlığıdır. 2000 yılında Erkekler lehine önemli bir farklılık olan bu boyutta yapılan çalışmalar sonucunda cinsiyet eşitsizliği farkı 2000 yılında \% 16 iken 2013 yılında \% 6'a gerilemiştir. 2013 yılı itibariyle 2000 yılındaki farka göre oldukça azalmıştır. Dünya genelinde olduğu gibi Türkiye'nin bu dönemde cinsiyet eşitsizliğini giderme anlamında önemli bir başarı sağladığı söylenebilir.

Bazı bölgesel eşitsizliklerin hala devam etmesine rağmen Türkiye EFA dönemi içerisinde eğitime erişimde önemli niceliksel gelişmeler sağlamıştır. Bununla birlikte eğitimden beklenen sonuçların uluslararası standartlarda olabilmesi için eğitimin kalitesinin arttırılmasına yönelik çalışmaların gerçekleştirilmesi gerekmektedir. Çünkü EFA'nın cinsiyet eşitliği amacının kapsamı hem tüm kız ve erkeklerin eğitime erişimlerini sağlamak hem de uygun okul çevresi, ayrımcılıktan uzak uygulamalar ile kız ve erkeklerin potansiyellerini gerçekleştirmelerine imkân sağlayan fırsatlar bağlamında eğitimde hakkaniyeti gerçekleştirmektir (EFA, 2014, s.5). Eğitimde hakkaniyet ancak tüm bireylere kaliteli bir eğitim hizmeti sağlamak ile mümkün olacaktır. 


\subsection{Eğitimde Kalite}

Bireylerin eğitim hizmetinden faydalanmaları uzun yıllar boyunca birçok ülkenin önemli hedefleri arasında yer almıştır. Bu kapsamda öncelikle okula erişim konusu üzerinde önemli çalışmalar yürütülmüştür. Fakat eğitimden beklenen faydayı elde etmek için sadece bireylerin okula erişimlerinin sağlanması yeterli olmamaktadır. UNESCO'nun 2014 yılında yayınladığı "Herkes için Eğitim" raporunda Dünya'da milyonlarca öğrencinin ilköğretime erişmesine rağmen temel okuma ve matematik becerilerine sahip olmadığı belirtilmektedir. Rapora göre; Dünya'da ilköğretim çağında 650 milyon ilköğretim öğrencisi bulunmakta, bunlardan en az 250 milyonunun temel okuma ve matematik becerilerinden yoksun bulunmaktadır. Öğrencilerin 120 milyonunun ilköğretime erişim imkânı bulunmazken geriye kalan 130 milyon öğrenci okulda minimum 4 yıl geçirmesine rağmen temel beceri düzeyine ulaşamamaktadır. Bu durum "küresel öğrenme krizi" olarak adlandırılmakta ve eyleme geçilmenin çok önemli olduğuna vurgu yapılmaktadır.

Bu noktada önemli olan husus bireylerin bilişsel gelişimlerini destekleyen kaliteli eğitim almalarıdır. Bu nedenle EFA'nın 6. amacı "Başta okuryazarlık, sayısal beceri ve gerekli yaşam becerileri olmak üzere, herkes tarafından kabul edilen ve ölçülebilen öğrenme sonuçlarını başararak, eğitimin kalitesini tüm yönleriyle iyileştirme ve eğitimde mükemmelliği sağlama" şeklinde ifade edilmiştir (UNESCO, 2000). Eğitimde kalite; 1990 yılında gerçekleştirilen Jomtien Deklarasyonunda, eğitimde eşitliğin başarılması için bir ön şart olarak kabul edilmiş, 2000 yılındaki Dakar Eylem Çerçevesinde ise kaliteli eğitime erişimin her çocuk için bir hak olduğu açık bir şekilde vurgulanmıştır (UNESCO, 2004, s.29). Çok boyutlu bir kavram olan kalite, eğitim siteminin nasıl organize edildiği ve yönetildiği, öğrenmenin içeriğinin ne olduğu, elde edilen öğrenme düzeyini, öğrenme ortamlarında neler yapıldığını ve öğrenme çıktılarını kapsamaktadır (UNESCO, 2002, s.80).

Eğitim sisteminin kalitesini etkileyen birçok faktör bulunmaktadır. Bu nedenle eğitimde kalitenin arttırılması çok yönlü çabaları gerekli kılmaktadır. Türkiye 2000'li yıllardan günümüze özellikle niceliksel olarak önemli gelişmeler gerçekleştirmiştir. Okul öncesinden yükseköğretime kadar eğitimin her kademesinde okullaşma oranları bu dönem içinde ciddi oranda yükselmiş temel eğitim kademesinde bu oran \% 100 'e yaklaşmıştır. Eğitimde gerçekleşen bu hacimsel genişleme nedeniyle Türkiye eğitime yapılan harcamalar bu dönemde artış göstermiştir. Örgün eğitime GSYH'da ayrılan kamu harcamalarının payı 2000 yılında \% 2,5 iken, 2005'te \% 2,8, 2010 'da \% 3,5 ve 2012' de ise \% 3,9'a çıkmıştır (OECD, 2015, s. 260). 2010 yılında OECD ülkeleri eğitim sistemlerine GSYH'nın ortalama \% 6,3'ünü ayırmıştır (OECD, 2013). Türkiye'nin eğitime GSYH'dan ayırdığı pay OECD ortalamasına göre oldukça geride kalmaktadır.

Herkes için kaliteli eğitim imkânlarının geliştirilmesi için ihtiyaç duyulan kaynaklar kadar yeterli eğitici personele ve uygun seviyedeki öğrenci öğretmen oranlarına gereksinim vardır. Öğrenci-öğretmen oranı EFA hedefleri kabul edildikten sonra amaç 6 da gerçekleştirilen ilerlemenin değerlendirilmesinde anahtar ölçek olarak kullanılmaktadır (UNESCO, 2014, s.85). Türkiye'de bu dönem içinde ilköğretimde öğretmen ve öğretmen-öğrenci oranlarının değişimi Tablo 9'da verilmiştir. 
Tablo 9

Türkiye 2004-2015 Dönemi Illköğretimdeki Öğrenci, Öğretmen ve Öğrenci-Öğretmen Oranları

\begin{tabular}{|c|c|c|c|}
\hline \multicolumn{4}{|c|}{ İlköğretim } \\
\hline Öğretim Yılı & Öğrenci Sayısı & Öğretmen Sayısı & Oran \\
\hline 2004-2005 & 10.565 .389 & 401.288 & 26,33 \\
\hline 2005-2006 & 10.673 .935 & 389.859 & 27,38 \\
\hline 2006-2007 & 10.846 .930 & 402.829 & 26,93 \\
\hline $2007-2008$ & 10.870 .570 & 445.452 & 24,40 \\
\hline 2008-2009 & 10.709 .920 & 453.318 & 23,63 \\
\hline 2009-2010 & 10.916 .643 & 485.677 & 22,48 \\
\hline 2010-2011 & 10.981 .100 & 503.328 & 21,82 \\
\hline 2011-2012 & 10.979 .301 & 515.852 & 21,28 \\
\hline \multicolumn{4}{|c|}{ ilkokul } \\
\hline & Öğrenci Sayısı & Öğretmen Sayısı & \\
\hline 2012-2013 & 5.593 .910 & 282.043 & 19,83 \\
\hline 2013-2014 & 5.574 .916 & 288.444 & 19,33 \\
\hline 2014-2015 & 5.434 .150 & 295.252 & 18,41 \\
\hline \multicolumn{4}{|c|}{ Ortaokul } \\
\hline & Öğrenci Sayısı & Öğretmen Sayısı & \\
\hline 2012-2013 & 5.566 .986 & 269.759 & 20,64 \\
\hline 2013-2014 & 5.478 .399 & 280.804 & 19,51 \\
\hline 2014-2015 & 5.278 .107 & 296.065 & 17,83 \\
\hline
\end{tabular}

Kaynak: MEB (2015). Millî Eğitim İstatistikleri, Örgün Eğitim 2014/'15. s.13. Ankara.

Tabloya göre 2004-2005 öğretim yılında ilköğretim düzeyinde 10565389 öğrenciye karşılık 401288 öğretmen görev yapmaktadır. Öğretmen başına düşen öğrenci sayısı 26'dır. 2012 yılına kadar öğrenci sayısı yavaş artış göstermesine rağmen öğretmen sayısı \% 25 den fazla bir artış göstermiş ve öğrenci öğretmen oranı $21^{\prime}$ e düşmüştür. Öğrenci öğretmen oranlarındaki düşüş devam ederek 2015 yılında ilkokulda oran 18 iken ortaokulda 17 olarak gerçekleşmiştir. Küresel ölçekte 1999'dan 2011 yılına kadar ilköğretimdeki öğrenci öğretmen oranı 26'dan 24 gerilemiştir (UNESCO, 2014, s.85). Küresel ölçekteki ilerlemeye göre Türkiye bu konuda ciddi bir başarı göstermiştir.

Kaliteli eğitimi etkileyen en önemli faktörlerden biriside uygulanan öğretim programlarının içeriğidir. Türkiye daha önce 1997 yılında güncellenen ilköğretim programlarını güncel ihtiyaçlar doğrultusunda 2005 kapsamlı bir şekilde reforma tabii tutmuştur. Çoklu zekâ kuramına ve beyin temelli yaklaşıma göre öğrenci merkezli olarak hazırlanan yeni programda; düşündüren, sorgulayan, soru soran, araştıran ve üreten bireyler yetiştirmenin hedeflendiği belirtilmiştir (MEB, 2006c, s.80).

Etkili öğretim ve öğrenim için hem öğretmenlerin hem de öğrencilerin kaliteli eğitim materyallerine intiyaçları vardır. Küresel düzeyde öğrencilerin ders kitaplarına erişememesi hala temel bir sorun olarak durmaktadır (UNESCO, 2014, s. 87). Türkiye açısından da sıkıntılı olan bu konuda 2001-2002 yılında ilköğretim öğrencilerine parasız ve ödünç ders kitabı dağıtılması uygulamasına başlanmıştır. Bu uygulamanın devamı niteliğinde 2003-2004 eğitim ve öğretim yılında ise resmi ilköğretim okullarında öğrenim gören öğrencilerin zorunlu ders kitapları MEB tarafından parasız dağıtılmaya başlanmıştır (Bilasa,2012, s.101) .

Eğitim kalitesinin belirlenmesindeki en kesin yöntem öğrenme kazanımlarının doğrudan değerlendirilmesidir. Bu tip değerlendirmeler çeşitli uluslararası kuruluşlar tarafından 1960'lı yılların ortalarından bu yana eğitim sistemlerinin kalitesini ve uygulamakta oldukları eğitim politikalarının öğrencilerin bilgi ve beceri edinmeleri üzerindeki etkinliğini belirlemek için gerçekleştirilmektedir. Uluslararası alanda yapılan bu çalışmaların en önemli 
olanları IEA tarafından yapılan TIMSS ve PIRLS ile OECD'nin gerçekleştirdiği PISA araştırmalarıdır. Türkiye özellikle TIMSS ve PISA çalışmalarına $2000^{\prime}$ li yıllardan bu yana birkaç döngü hariç sürekli katılmaktadır. Bu çalışmalardan elde edilen verilen eğitim kalitesinin bir göstergesi olarak düşünülmektedir.

Illköğretim kademesindeki 4 ve 8 . Sınıf düzeyindeki öğrencilerin matematik ve fen başarılarının değerlendirildiği TIMSS uygulaması ilk defa 1995 yılında uygulanmıştır. Türkiye, 1995 yılından bu yana her dört yılda bir gerçekleştirilen TIMSS çalışmasına Türkiye 1999, 2007 ve en son 2011 yılında katılmıştır. Türkiye'nin matematik alanında gösterdiği başarı puanları ve sıralaması Tablo 10 'da verilmiştir.

Tablo 10

Türkiye'nin TIMSS Uygulamasındaki Matematik Başarı Durumu

\begin{tabular}{cccccc}
\hline Uygulama Yılı & $\begin{array}{c}\text { Türkiye } \\
\text { Ortalama } \\
\text { Puanı }\end{array}$ & $\begin{array}{c}\text { Uluslararası } \\
\text { Ortalama Puanı }\end{array}$ & $\begin{array}{c}\text { Alt Düzey } \\
\text { Altında } \\
\text { Kalan } \\
\text { Öğrenci } \\
\text { Yüzdesi }\end{array}$ & $\begin{array}{c}\text { Türkiye'nin } \\
\text { Sırası }\end{array}$ & $\begin{array}{c}\text { Katılan } \\
\text { Ülke } \\
\text { Sayısı }\end{array}$ \\
\hline 1999 & 429 & 487 & 35 & 31 & 38 \\
\hline 2007 & 432 & 450 & 41 & 30 & 49 \\
\hline 2011 & 452 & 478 & 33 & 24 & 45 \\
\hline
\end{tabular}

Kaynak: Yücel, C., Karadağ, E., \& Turan, S. (2013). TIMSS 2011 Ulusal Ön Değerlendirme Raporu. Eskişehir Osmangazi Üniversitesi, Eğitim Fakültesi, Eğitimde Politika Analizi Raporlar Serisi I. Eskişehir.

Tabloya göre Türk öğrencilerinin 1999'dan 2011 yılına ortalama matematik başarı puanları yaklaşık olarak 20 puanlık bir artış göstermiştir. Fakat Türkiye'nin matematik başarı puan ortalaması uluslararası ortalamanın altında kalmıştır. Ülke sıralaması açısından 2011 yılında Türkiye 45 ülke arasından 24. olabilmiştir. Türkiye eğitim sistemi açısından asıl sorunlu alan alt düzey altında kalan öğrencilerin çokluğudur. Bu öğrenciler TIMSS'in tanımladığı asgari düzeye ulaşamayan yani ilgili ders alanında en temel düzeyde bilgi ve beceriye sahip olamayan öğrencileri temsil etmekte ve eğitim sistemlerinin en zayıf noktasını oluşturmaktadır. Bu öğrencilerin oranı Türkiye'de 12 yıllık süreçte \% 35-40 gibi yüksek bir oranda seyretmiştir. TIMSS tarafından tanımlanmamış olan bu gruptaki öğrenci yüzdeleri gelişmiş ülkeler için \% 10 civarındadır (Yücel, Karadağ ve Turan, 2013, s.28). Bu araştırma sonucu ilköğretim kademesinin sonundaki her üç öğrenciden birinin temel düzeyde matematik bilgi ve becerisine sahip olmadı̆̆ını göstermektedir. Bu durum fen dersi içinde benzer bir durum sergilemektedir. Bu sonuçlar 2000'den günümüze Türkiye'de eğitim sistemi üzerinde gerçekleştirilen çalışmaların, eğitime erişim konusunda etkili olduğu fakat öğrencilerin kaliteli eğitim almalarını sağlamadığını göstermektedir. Eğitimde kalite hala Türkiye'nin çözmesi gereken bir sorun olarak durmaktadır.

\section{SONUC}

Bir insan hakkı olan eğitim, küreselleşmenin yaşandığı günümüzde toplumlar ve ülkelerin sürdürülebilir kalkınma ve barışı devam ettirebilmelerinde anahtar bir role sahiptir (UNESCO, 2000, s.8). Bu nedenle ülkeler eğitim sistemlerini daha etkili hale getirmek için sürekli reform hareketleri gerçekleştirmektedir. Tüm bu reform hareketlerinin temel amacı eğitim ve okulları geliştirerek onları daha etkili kılmaktır (Aksit, 2007). Reform hareketleri sadece yerel aktörler tarafından değil uluslararası çeşitli kuruluşlar tarafından hem 
yönlendirilmekte hem de izlenmektedir. UNESCO'nun yürüttüğü Herkes için Eğitim Hareketi bu kapsamdaki en önemli eğitim girişimidir.

Türkiye kuruluşundan bu yana eğitimin çeşitli alanların sürekli değişiklikler ve düzenlemeler yapan bir ülkedir. Özellikle Avrupa Birliği sürecinin hız kazandığı 2000'li yılların başından itibaren Türkiye'nin her açıdan dış Dünya ile olan etkileşimi güçlenmeye başlamıştır. Bu etkileşimin bir sonucu olarak çeşitli alanlarda olduğu gibi eğitim sistemi üzerinde yoğun bir şekilde reformlar yapılmaya başlanmıştır. 2015 yılı itibariyle 78 milyon nüfusa sahip olan Türkiye'de örgün eğitim kademelerinde 18 milyon öğrenci ile 800000 civarında eğitim personeli bulunmaktadır. Bu devasa büyüklükteki sistemi etkin bir şekilde reform etmek oldukça zor bir iştir. Eğitimdeki ilerlemenin sürekli izlenmesi reformların aksayan taraflarının tespiti açısından gereklidir. Bu nedenle Türkiye'de gerçekleştirilen eğitim reform ve uygulamalarını EFA kapsamında belirlenen 6 amaç doğrultusunda değerlendirmek 15 yıllık süreçteki eğitim sistemimizdeki ilerlemeyi belirlemek açısından önemlidir.

Dünyadaki öneminin anlaşılmasına rağmen bu dönem içinde Türkiye'deki okul öncesi eğitim alanındaki geliş̧meler çok sınırlı düzeyde kalmıştır. Bu kademe için okullaşmada kısmi bir gelişme sağlanmasına rağmen istenen düzeye ulaşılamamıştır. Bununla birlikte bu hizmetten yararlanma konusunda bölgeler arası eşitsizlikler hala devam etmektedir. Evrensel ilköğretimde Türkiye oldukça başarılı bir performans göstererek okullaşma oranlarını \% 100 'lere çok yakın bir seviyeye çıkarmayı başarmıştır. Cinsiyet eşitsizliği bu kademe için giderilmiştir. Fakat diğer alanlarda olduğu gibi kaliteli eğitim ve okulu tamamlama konularında sıkıntılar devam etmektedir.

Ortaöğretim açısından bakıldığında zorunlu eğitimin 12 yıla çıkarılması ile bu kademedeki çağ nüfusunun okullaşma oranları yükselmiştir. Kız çocuklarının bu eğitimden erkekler ile aynı oranda faydalanması sağlanmıştır. Bu kademe için devam eden önemli sorunlardan birisi genç ve yetişkinlerin hayatta ihtiyaç duyacakları bilgi ve beceriler ile okulda öğrendikleri beceriler arasındaki uyumsuzluklarının devam etmesidir. Genel ortaöğretim ile mesleki ortaöğretim arasındaki dengede bu dönem içinde düzeltilemeyen başka bir sorun alanıdır. Yetişkinlerin okuryazarlık oranı yükseltilerek okumaz yazmaz oranı \% 5'in altına indirilmiştir. Bu grup içindeki kadınlar aleyhine olan durum hala devam etmektedir. Bununla birlikte okuryazarlık programlarının sadece okuma ve yazma değil günümüz dünyasında bireylerin ihtiyaç duyacakları temel yaşam becerilerini de kapsayacak şekilde genişletilmesi ve sunumunun sağlanması gerekmektedir.

Türkiye'nin EFA döneminde cinsiyet eşitliği konusunda oldukça başarılı bir performans göstermiştir. EFA kapsamında üç boyut altında değerlendirilen cinsiyet eşitliğine ilköğretim düzeyinde ulaşılmıştır. Ortaöğretim düzeyinde ise bu kademenin 2012 yılında zorunlu eğitim kapsamına alınması ile kısa zamanda cinsiyet eşitliği farkı \% 5'in altına inmiştir. +15 yaş nüfus açısından 2000 yılından 2015'e yetişkin okuryazarlığı alanında cinsiyet eşitsizliği kadınlar lehine ciddi bir ilerleme göstermiştir. Fakat fark hala kapatılamamıştır. Bu noktada kadınların sosyoekonomik durumları dikkate alınarak yeni proje ve politikaların uygulanması gerekmektedir.

Eğitimde kalite konusunda; öğrenci-öğretmen oranlarındaki iyileşme, öğrencilerin eğitim kitaplarına erişimin sağlanması, istihdam edilen öğretmen sayısındaki artış gibi niceliksel gelişmelere rağmen Türkiye'nin performansı niteliksel olarak ciddi sorunların devam ettiğini göstermektedir. Eğitimin nihai amacı öğrencilerin öğrenmelerini sağlamaktır. Uluslararası alanda gerçekleştirilen ve ülkelerin eğitim kalitelerinin bir ölçüsü olarak kabul edilen çalışma sonuçlarına göre Türkiye' deki öğrencilerin performansları düşük düzeyde kalmaktadır. Örneğin, TIMSS sonuçlarına göre Türkiye'nin performansı 1999'dan 2011'e hemen hemen aynı seviyede 
kalmıştır. Türkiye'de eğitim harcamalarının artmasına rağmen OECD ülkeleri arasında eğitim başarısı açısından en alt düzeyde bulunmaktadır (Aksit, 2007). Bu sonuçlar Türkiye'de eğitime ayrılan kaynak artışının ve reform çabalarının etkili olmadığını göstermektedir.

Ulusal ve uluslararası düzeyde eğitim ve öğretimin kalitesinin geliştirilmesi eğitim politika tartışmalarının merkezini oluşturmaktadır (EC, 2015, s.7). EFA amaçları kapsamında Türkiye'nin bu dönemdeki performansı niceliksel olarak iyi olmasına rağmen niteliksel olarak bir ilerlemenin sağlanamadığını göstermektedir. Niteliksel gelişim sağlanamadığı sürece eğitimden beklenen sonuçların oluşmayacağı bilinmelidir. Çünkü ekonomik performans ve sosyal değişim için eğitim başarılarının yükseltilmesi temel olarak görülmektedir (Sammons, 2006). Türkiye'nin 2015 sonrası eğitim stratejisini ve reform çalışmalarını kalite öncelikli planlaması, bütüncül bir yaklaşım çerçevesinde ve tüm eğitim paydaşlarının katılımını esas alan demokratik yöntemlere göre belirlemesi ve uygulaması gerekmektedir.

\section{KAYNAKLAR}

AÇEV-ERG (2013). Erken çocukluk eğitimi ve "4+4+4" düzenlemesi. Politika Raporu. İstanbul.

Aksit, N. (2007). Educational reform in Turkey. International Journal of Educational Development. 27, 129-137.

Bekman, S. ve Gürlesel, C. F. (2005). Doğru başlangıç: Türkiye'de okul öncesi eğitim. (TÜSiAD Raporu). İstanbul: TÜsiAD T/2005-05/396.

Başbakanlık (2008). Toplumsal cinsiyet eşitliği ulusal eylem planı 2008-2013, Ankara.

Bilasa, P. (2012). Türkiye'de ilköğretimin tarihsel gelişimi (1970-2010). (Yayınlanmamış Doktora Tezi). Gazi Üniversitesi Eğitim Bilimleri Enstitüsü, Ankara.

Çengel, Y. A. (2005). AB sürecinde rasyonel eğitime geçiş: vizyon ve misyon. Milli Eğitim Dergisi, 167.

Dünya Bankası (2011). Türkiye'de temel eğitimde kalite ve eşitliğin geliştirilmesi: zorluklar ve seçenekler. Rapor No: 54131-TR.

Dünya Bankası (2013). Türkiye'de erken çocukluk eğitiminin yaygınlaştırılması ve geliştirilmesi. Rapor No: 77723-TR.

DPT (2010). Binyıl kalkınma hedefleri raporu Türkiye 2010. Ankara: Devlet Planlama Teşkilatı.

European Commission (2015). Assuring quality in education: policies and approaches to school Evaluation in Europe. Eurydice Report. Luxemboury: Publications Office of the European Union.

ERG (2012). Meslek eğitiminde kalite için işbirliği mesleki ve teknik eğitimde güncellenmiş durum analizi. İstanbul: Eğitim Reformu Girişimi.

ERG (2013). Eğitim izleme raporu 2013. İstanbul: Eğitim Reformu Girişimi.

Gündüz, M. (2011). Zorunlu ve Kesintisiz Eğitimin Kısa Tarihi. Eğitime Bakış. 7(21), 3-10.

Hanushek, E. A. and Wossmann, L. ( 2007). The role of education quality in economic growth. Policy Research Working Paper 4122, World Bank, Washington, D.C.

Heckman, J. ve Cunha, F. (2007). The technology of skill formation. American Economic Review 97(2), 31-47.

McMahon, W. (2006). Education finance policy: Financing the nonmarket and social benefits. Journal of Education Finance, 32(2), 264-284. 
MEB (2005). 2006 Yılı Mali Bütçesine Iliş̧kin Rapor. Ankara: Araştırma ve Koordinasyon Kurulu Başkanlığı.

MEB (2006a). 2007 Bütçesine Iliş̧kin Rapor. Ankara: Strateji Geliştirme Başkanlığı.

MEB (2006b). Türkiye'nin başarısı için itici güç. Hayat boyu öğrenme politika belgesi. Ankara: Projeler Koordinasyon Merkezi Başkanlığı.

MEB (2006c). Eğitimde değişim yılları 2003-2006. Ankara: Millî Eğitim Basımevi. MEB (2007a). Temel eğitime destek programı (TEDP). (1.Baskı). Ankara: Projeler Koordinasyon Merkezi Başkanlı̆̆ı.

MEB (2007b). Yetişkinler okuma yazma öğretimi ve temel eğitim programı (I. ve II. Kademe). Ankara: Milli Eğitim Bakanlığı.

MEB (2009). Milli Eğitim Bakanlığı 2010-2014 Stratejik Planı. Ankara: Strateji Geliştirme Başkanlığı.

MEB (2014a). Millî Eğitim Bakanlığı Okul Öncesi Eğitim Ve İlköğretim Kurumları Yönetmeliği. http://mevzuat.meb.gov.tr/html/ilkveokuloncyon 0/ilkveokuloncyon 0.html, (Erişim Tarihi: 2016, 5 Mayıs).

MEB (2014b). Hayat boyu öğrenme strateji belgesi 2014-2018. Ankara: Milli Eğitim Bakanlığı.

MEB (2014c). 2001-2014 yılları arası yetişkin okuma yazma çalışmaları. http://okumayazma.meb.gov.tr/sites/default/files/sites/default/files/dosyalar/2001-2014.pdf, (Erişim Tarihi: 2015, 21 Kasım).

MEB (2015). Millî eğitim istatistikleri, örgün eğitim 2014/'15. Ankara: Milli Eğitim Bakanlığı.

Sammons, P. (2006). School effectiveness and equity: making connections. Keynote speech made at the International Congress for School Effectiveness and Improvement, Florida.

Schultz, T. W. (1961). Investment in human capital. American Economic Review. 51, 1-17.

OECD (2013). Education at a Glance 2013. Paris: OECD.

OECD (2015). Education at a Glance 2015: OECD Indicators. Paris: OECD.

UN (2000). United Nations Millennium Declaration. Resolution adopted by the General Assembly. New York, USA: United Nations.

UNESCO (2000). The Dakar Framework for Action, Education for All: Meeting our Collective Commitments, adopted by the World Education Forum (Dakar, Senegal, 26-28 April 2000). Paris: UNESCO.

UNESCO (2002). Education for All: Is the world on track? UNESCO, Paris.

UNESCO (2004). EFA Global Monitoring Report 2005:The Quality Imperative. Paris: UNESCO.

UNESCO (2010). EFA Global Monitoring Report 2010: Reaching the marginalized. Paris: UNESCO.

UNESCO (2014). EFA Global Monitoring Report 2013-2014:Teaching and Learning: Achieving Quality for All. Paris: UNESCO.

UNESCO (2015). EFA Global Monitoring Report 2000-2015: Achievements and Chalenges. Paris: UNESCO.

UNESCO (2015a). EFA Global Monitoring Report GENDER AND EFA 2000_2015: Achievements and Challenges. Paris: UNESCO.

TEDMEM (2015). 2015 Eğitim Değerlendirme Raporu. Ankara: Türk Eğitim Derneği.

TÜiK (2012). iSTATISTiK GÖSTERGELER 1923-2011. Ankara. 
TÜSIAD (2008). Türkiye'de Toplumsal Cinsiyet Eşitsizliği: Sorunlar, Öncelikler Ve Çözüm Önerileri, Ankara.

Yıldırım, A. ve Şimşek, H. (2011). Sosyal Bilimlerde Nitel Araştırma Yöntemleri. Ankara: Seçkin Yayıncılık.

Yıldız, A. (2010). Birinci Kademe Okuma-Yazma Kurslarına Katılan Yetişkinlerin Matematik Becerileri Üzerine bir Araştırma. Eğitim ve Bilim. 35(158), 28-43.

Yücel, C., Karadağ, E., ve Turan, S. (2013). TIMSS 2011 Ulusal Ön Değerlendirme Raporu. Eskişehir Osmangazi Üniversitesi, Eğitim Fakültesi, Eğitimde Politika Analizi Raporlar Serisi I. Eskişehir.

Woessmann, L. (2003) Educational Production in East Asia: The Impact of Family Background and Schooling Policies on Student Performance. SSRN eLibrary.

http://okuma-yazma.meb.gov.tr/tarihce, (Erişim Tarihi: 2015, 15 Kasım). 


\section{SUMMARY}

Many countries at local level, supranational actors like UNESCO and OECD on the global scale make many reforms towards the development of education systems because of the crucial functions of education. One of the most important global movement in education is 'Education for All' (EFA) initiated in 1990 by UNESCO. An overall assessment of the EFA movement was made at World Education Forum in 2000 and the six EFA targets were identified to be achieved by 2015 . The main topics of the specified six goals are; early childhood education, basic education, youth and adult skills, adult literacy, gender equality and quality education.

Turkey has carried out intensive work on educational reforms in every aspects of education since the early 2000s. It has a population of 78 million, around 800000 education staff with 18 million students in formal education levels in 2015. It is a quite difficult mission to reform this huge size of the system effectively. Continuous monitoring of progress in education is important to identify the problematic issue of reforms and for steps to be taken towards a solution. Therefore, it is vital to assess educational reforms and policies according to EFA six goals to determine the educational development process in the 15 years period in Turkey.

The aim of this study is to investigate and evaluate Turkey's educational policies and practices from a broad perspective at the period of 2000-2015 according to six EFA goals. Therefore educational regulations, policies, training programs, projects and geographical access, quantitative development and educational spending in Turkey have been analyzed in the framework of six EFA golas. In the study, the qualitative research approach was applied and in the analysis of data, document analysis technique was used.

In the last 15 years, Turkey has shown significant quantitative improvements in early childhood education but still it is behind the OECD countries to participation in this education. For example, enrolment rate of 3-year-old to pre-school is 7\% in Turkey while 74\% in OECD countries; for 4-year old, $36 \%$ and $85 \%$ respectively. Also there is some disparities in enrolment rate of early childhood education in the country. Turkey should pay more attention to pre-school education in the next period.

Accessing to primary education is the significant priorities of Turkey educational policies for many years. Turkey's school enrollment rate is $96.30 \%$ for primary school and $94.35 \%$ for lower secondary school in 2014-15 academic year. Although Turkey is very close to the target of universal primary education, it was slightly below the target. In the post 2015 period, Turkey should implement specific policies and projects to individuals out of basic education and students who have difficulties to continue to school.

From the point of young and adults skilss we can say that there is a significant increase in enrollment rates in secondary education level, gender equality was achieved and non-formal education program diversity was provided in the 15 years period. But despite the implementing of compulsory secondary education in 2012, it cannot be provided access to education for all individuals and the share of vocational education in secondary education was not increased to the desired level.

Adult illiteracy rate around $15 \%$ in 2000 has been reduced to below $5 \%$ in 2015 . This result shows that more than $50 \%$ improvement in adult literacy. But there is still a considerable number of illiterate citizens in the +15 age group, and a large portion of them are women. Turkey should prepare projects taking into particularly women's socio-economic, geographical status and educational background to achieve literacy skills of all age group in the post-2015 education agenda.

Turkey has made substantial progress in gender equality during the EFA 2015 period. The sex ratio in primary education was $88.54 \%$ in 2000 and is more than $100 \%$ in 2015 . Gender disparities in both primary and lower secondary level was disappeared. The sex ratio in upper secondary level was $95.40 \%$ in 2015 . The most significant gender disparity in Turkey is in adult literacy. Gender inequality gap between men and women was $16 \%$ in 2000 , and decreased to $6 \%$ in 2013 . But there is still a regional disparities in adult literacy in Turkey.

Despite the increase in the number of teachers who are employed in the system, providing students access to the school books as a free and improvements in the pupil-teacher ratio, Turkey's 
educational performance shows that qualitative problems in education are continuing seriously. According to the results of some study carried out internationally, performance of students in Turkey remains low. For example, Turkey's performance in the TIMSS results from 1999 to 2011 has remained almost the same level. These results indicate that the effect of the increase in resources allocated to education and reform efforts in Turkey not to provide quality education.

Although Turkey has achieved good quantitative improvements in education in this period, qualitative improvements have been low level. In conclusion for the post 2015 era Turkey should plan educational reforms and strategies focusing on education quality issues, determine the framework of an integrated approach and to provide participation of all stakeholders in education sector according to the principles of democratic methods and practices. 